\title{
Influence of distributary channels on sediment and organic matter supply in event-dominated coastal margins: the Po prodelta as a study case
}

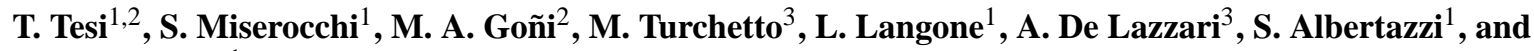 \\ A. Correggiari ${ }^{1}$ \\ ${ }^{1}$ Istituto Scienze Marine CNR - Sede di Bologna, Via P. Gobetti, 10140129 Bologna, Italy \\ ${ }^{2}$ College of Oceanic and Atmospheric Science, Oregon State University, Corvallis, OR 97331, USA \\ ${ }^{3}$ Istituto Scienze Marine CNR - Sede di Venezia, Castello 1364/A, 30122 Venezia, Italy
}

Received: 28 September 2010 - Published in Biogeosciences Discuss.: 28 October 2010

Revised: 24 January 2011 - Accepted: 8 February 2011 - Published: 15 February 2011

\begin{abstract}
From November 2008 through May 2009, the Po river (Italy) experienced several floods exceeding $5000 \mathrm{~m}^{3} \mathrm{~s}^{-1}$. This long series of events ended with a large flood in early May $2009\left(\sim 8000 \mathrm{~m}^{3} \mathrm{~s}^{-1}\right)$. An eventresponse sampling was carried out in the Po prodelta in April-May 2009 to characterize the preservation of this series of floods in the sediment record and to describe the event-supply and deposition of riverborne particulate material during the May 2009 flood. The water sampling was carried out early in the event under conditions of moderate river flow $\left(\sim 5000 \mathrm{~m}^{3} \mathrm{~s}-1\right)$ and $24 \mathrm{~h}$ later during the peak discharge $\left(\sim 8000 \mathrm{~m}^{3} \mathrm{~s}^{-1}\right)$. Sediment cores were collected in the prodelta before and after the peak flood. At each station, profiles of conductivity, transmittance, and fluorescence were acquired. Surface and bottom waters were sampled to collect sediments in suspension. In addition, a few days before the May 2009 event, suspended sediments were collected at Pontelagoscuro gauging station, $\sim 90 \mathrm{~km}$ upstream from the coast. Biogeochemical compositions and sedimentological characteristics of suspended and sediment samples were investigated using bulk and biomarker analyses. Furthermore, ${ }^{7} \mathrm{Be}$ and radiographs were used to analyze the internal stratigraphy of sediment cores.

During moderate flow, the water column did not show evidence of plume penetration. Stations re-occupied $24 \mathrm{~h}$ later exhibited marked physical and biogeochemical changes during the peak flood. However, the concentration of
\end{abstract}

terrestrially-derived material in surface waters was still less than expected. These results suggested that, since material enters the Adriatic as buoyancy-driven flow with a reduced transport capacity, settling and flocculation processes result in trapping a significant fraction of land-derived material in shallow sediments and/or within distributary channels.

Although numerous discharge peaks occurred from November 2008 through April $2009\left(4000-6000 \mathrm{~m}^{3} \mathrm{~s}^{-1}\right)$, sediment cores collected in late April 2009 showed lack of event-strata preservation and reduced ${ }^{7} \mathrm{Be}$ penetrations. This suggested that only a small fraction of the sediment supply during ordinary events reaches the deepest region of the prodelta (12-20 $\mathrm{m}$ water depth). As a result, these eventstrata have a thickness not sufficient to be preserved in the sediment record because of post-depositional processes that destroy the flood signal.

Stations in the northern and central prodelta were reoccupied after the peak of the May 2009 flood. Based on ${ }^{7} \mathrm{Be}$ and radiographs, we estimated event layers of 17 and $6 \mathrm{~cm}$ thickness, respectively. Selective trapping of coarse material occurred in the central prodelta likely because of the geomorphologic setting of the central outlet characterized by an estuary-like mouth. Despite these settling processes, ligninbased parameters indicated that the composition of the terrigenous OC was fairly homogenous throughout the network of channels and between size-fractions. 


\section{Introduction}

Prodeltas are globally distributed sedimentary bodies located along the modern coastline. Although they gradually formed $6 \mathrm{kyr}$ ago after sea level stabilized, they have recently experienced significant changes in morphology because of human land use changes within watersheds (e.g., deforestation, damming, irrigation, etc.) that have reduced or enhanced sediment supply to the ocean (Syvitski et al., 2005a, b; Kettner and Syvitski, 2009; Syvitski et al., 2009). However, despite these anthropogenic modifications, deltas are still considered important long-term sinks of reduced carbon accounting for nearly half of the OC burial in marine sediments (Berner, 1987, 1989; Hedges and Keil, 1995). Therefore, even though prodeltas cover a small fraction of the oceanic seafloor, the $\mathrm{OC}$ sequestration in these systems contributes to the regulation of atmospheric $\mathrm{CO}_{2}$ concentrations on geologic time scale and might potentially store anthropogenically-derived $\mathrm{CO}_{2}$ in the form of reduced modern carbon (Blair et al., 2003; Goñi et al., 2005).

In this study we focused on the Po prodelta located in the north Adriatic Sea (Mediterranean Sea). In this system, the supply and accumulation of OC are highly episodic because of flood events that ensure a rapid supply and deposition of land-derived OC in the coastal ocean (Palinkas et al., 2005; Wheatcroft et al., 2006; Miserocchi et al., 2007; Tesi et al., 2008). Recently, event-dominated rivers like the Po have received renewed consideration as they account for $\sim 50 \%$ of the sediment supply to the ocean (Milliman and Syvitski, 1992). Therefore, it has been suggested in several studies that about half of the land-ocean exchange of particulate $\mathrm{OC}$ is driven by these event-dominated systems (Gomez et al., 2003; Leithold et al., 2006). As it is not feasible to individually study each watershed, several land-ocean studies have provided general conceptual models to discriminate the major geological and hydrological variables affecting the character of OC supplied to the ocean. For small mountainous rivers, Leithold et al. (2006) suggested that high sediment yields coupled with low weathering history enhances the preservation of the original upland-generated organic carbon signal because the bedrock material is constantly delivered from hillslopes to river channels. In parallel, Wheatcroft et al. (2010) indicated that river discharge exerts first-order control on the concentration and character of $\mathrm{OC}$ in eventdominated watersheds. According to the authors, mobilization of distinct pools of OC occurs at different discharges and the transport effectiveness of each pool is the product of flow frequency and transport magnitude (i.e., effective discharge).

In this manuscript, we propose the internal architecture of prodeltaic systems as an additional variable affecting the land-ocean exchange of particulate OC because it has been shown that their morphology influences the transfer of sediment to the coastal ocean. A global analysis of world deltas has been carried out by Syvitski et al. (2005b). The authors showed how deltas with a high number of distributary chan- nels produce hypopycnal plumes with reduced transport capacity. Under these conditions, sediments diffuse from the deltaic coastal zone as a buoyancy-driven plume, rather than as a momentum driven-flow. Because of the reduced plume penetration, river material has a high probability to flocculate and settle in shallow waters. In addition, trapping of riverborne material can occur within each distributary channel. This storage varies among channels because the response to the upstream discharge is generally not identical for each branch (Syvitski et al., 2005a; Syvitski and Kettner, 2007). As a result, the sediment and OC delivery to the ocean from each mouth is highly irregular throughout time and might not be coherent with the material supplied from the rest of the network of channels.

Although a multi-channels setting is a common feature of numerous prodeltas (Syvitski et al., 2005a), there is a lack of general understanding about the influence of prodeltaic architecture on supply and accumulations of OC in the ocean. In order to understand the land-ocean exchange of particulate material in a multi-branch setting, an event-response sampling was carried out in the northern Adriatic Sea (Mediterranean Sea) when the Po river experienced a significant flood event in May 2009. The Po delta consists of 5 major distributaries formed as result of human modifications and natural adjustments. The May 2009 event had a 20$\mathrm{yr}$ return period and it was the last in a series of frequent flood events. Suspended sediments supplied to the prodelta were collected during two periods of the May 2009 flood, including early in the event under conditions of moderate river flow $\left(\sim 5000 \mathrm{~m}^{3} \mathrm{~s}^{-1}\right)$ and later during peak discharge $\left(\sim 8000 \mathrm{~m}^{3} \mathrm{~s}^{-1}\right)$. In addition, sediment cores were collected after and before the peak discharge. Samples were analyzed using a multi-proxy approach that included determination of suspended sediment concentration (SSC), organic carbon $(\mathrm{OC})$, total nitrogen $(\mathrm{TN})$, alkaline $\mathrm{CuO}$ reaction products, carbon isotope compositions $\left(\delta^{13} \mathrm{C}\right.$ and $\left.\Delta^{14} \mathrm{C}\right)$, grain-size, and mineral surface area. In addition, ${ }^{7} \mathrm{Be}$ down-core profiles and radiographs, were used to estimate thickness and investigate the internal stratigraphy of the flood deposit.

The main goal of this time-series analysis was to asses the role of distributary channels in affecting the land-ocean exchange of particulate organic matter (OM) and characterize the non-steady-state OC deposition in event-dominated coastal margins and. First, we will provide background information about the Po river and prodelta that have been heavily studied since October 2000, when the Po river experienced a large flood event (i.e., EuroStrataform project). Then, we will focus on the short term variability of the suspended material collected in the prodelta during the May 2009 flood. Finally, sediment cores will be used to understand the timing of sediment accumulation and factors driving the emplacement of particulate $\mathrm{OM}$ in the prodelta during flood events. 

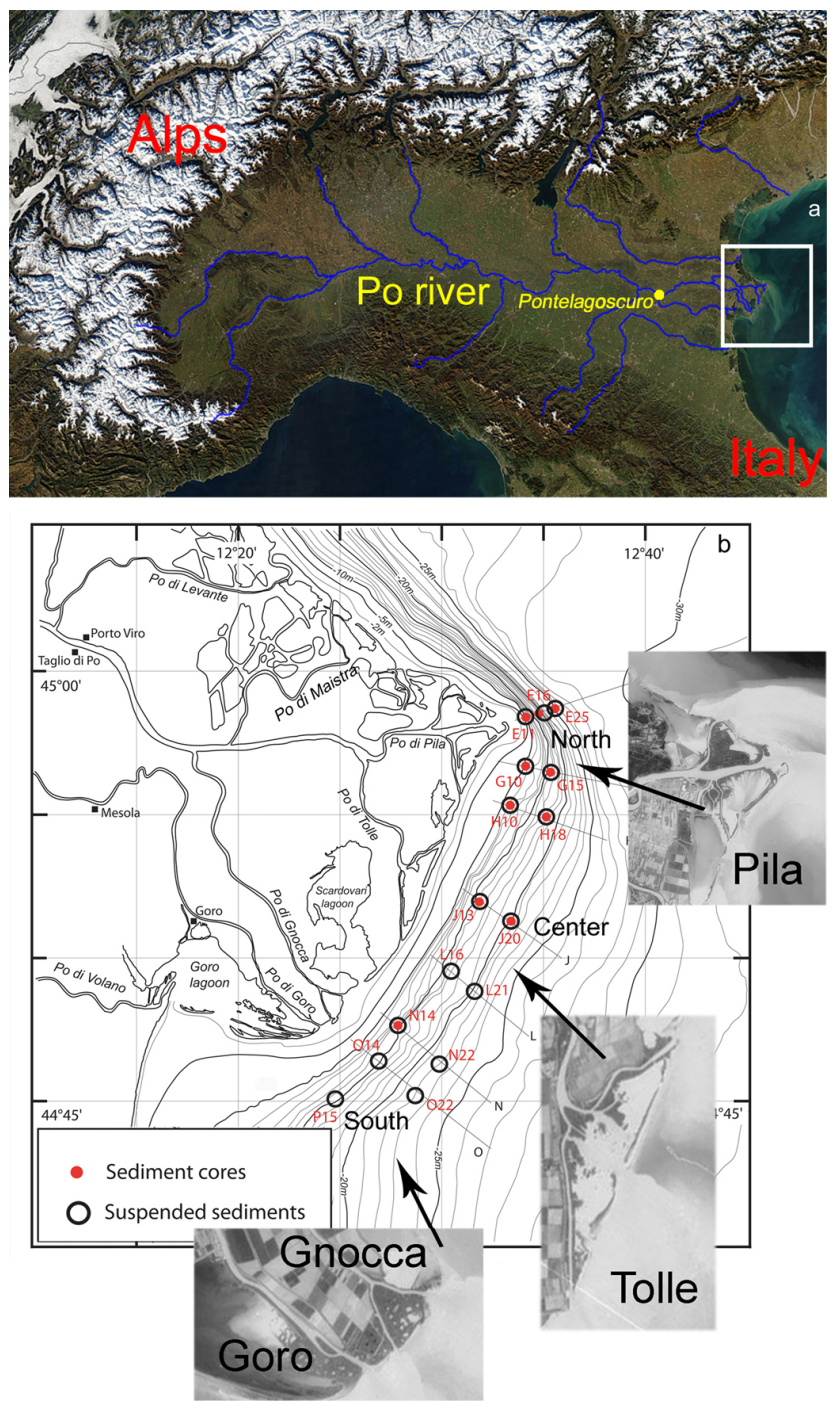

Fig. 1. (a) Satellite image of Northern Italy and the Po river drainage basin: open squares show the Po prodelta location (b) Map of the study area. Stations were grouped into subregions: north, center, south.

\section{Background}

\subsection{Po river and delta}

With over three millennia of human activity, the $71057 \mathrm{~km}^{2}$ Po watershed is one of the most agriculturally developed and populated areas in Europe. Over a third of the drainage basin is mountainous whereas the rest is composed of a wide, lowgradient alluvial plain (Fig. 1a). Its basin represents the confluence of Alpine (maximal relief $\sim 4500 \mathrm{~m}$ ) and Apennine (maximal relief $\sim 2000 \mathrm{~m}$ ) streams. The river typically experiences two discharge peaks, first in autumn because of the rainfall and later in spring mainly driven by snowmelt. Although these seasonal peaks, a third of the total flow is regulated by reservoir management for hydropower and ir- rigation purposes. The Po river has a mean freshwater discharge of $1525 \mathrm{~m}^{3} \mathrm{~s}^{-1}$ (Boldrin et al., 2005) recorded at Pontalagoscuro gauging station (Fig. 1). Downstream Pontelagoscuro, the river splits in 5 major distributaries (Fig. 1b): Maistra, Pila, Tolle, Gnocca, and Goro, from north to south, respectively (Fig. 1b, c). The main distributary channel is Pila, delivering $74 \%$ of the sediment load whereas Maistra, Tolle, Gnocca, and Goro supply the remaining $1 \%, 7 \%, 10 \%$, and $8 \%$, respectively. Fluxes through distributary channels are variable with time fluctuating between periods of sediment accumulation and net erosion. During moderate river discharge, Pila supplies $61 \%$ of the fresh water entering the delta, while Maistra, Tolle, Gnocca, and Goro supply the remaining 3\%, 12\%, 16\% and 8\%, respectively (Syvitski et al., 2005a).When the river experiences large floods, the relative proportion between different distributaries significantly changes. For example, in the October 2000, during the flood of the century, the relative fresh water input of Pila channel dropped to $40 \%$ while Maistra, Tolle, Gnocca, and Goro distributaries considerably increased their relative supply accounting for $8,12,20$, and $20 \%$ of the total fresh water entering the delta, respectively (Piano stralcio per l'Assetto Idrogeologico del Delta_PAI, repot by the Autorità di bacino fiume Po, Parma).

The sediment deposition in the prodelta occurs because of episodic events. Recently the river has experienced several major floods, defined as events with mean water discharge rates exceeding $7000 \mathrm{~m}^{3} \mathrm{~s}^{-1}$. The most recent events occurred in November 1994, October 2000, and November 2002. The October 2000 flood was particularly significant as the river flow exceeded $9650 \mathrm{~m}^{3} \mathrm{~s}^{-1}$ (Fig. 2a) (Boldrin et al., 2005; Palinkas et al., 2005; Wheatcroft et al., 2006). A rapid-response cruise was organized to collect sediment cores along and across the Po prodelta in December 2000 to understand the initial deposition of the flood deposit. The stations were re-occupied eight times over the next 2 yr by an international team of American and European scientists as part of the EuroSTRATAFORM project, in order to capture the temporal evolution of the initial flood deposit. Results from this international effort were published in several manuscripts (Fox et al., 2004; Boldrin et al., 2005; Palinkas et al., 2005; Syvitski et al., 2005a; Wheatcroft et al., 2006; Milligan et al., 2007; Miserocchi et al., 2007) and they will be used in this study to better constrain our results. In order to be consistent with previously published studies, we sampled the same station locations occupied during the EuroSTRATAFORM project.

\subsection{The May 2009 flood event}

The May 2009 flood was triggered by the combination of spring snow melting with a atmospheric perturbation coming from the Atlantic ocean. The winter 2008-2009 was particularly wet allowing for significant accumulation of snow on the Alps (Fig. 1a). This water reservoir was subsequently 

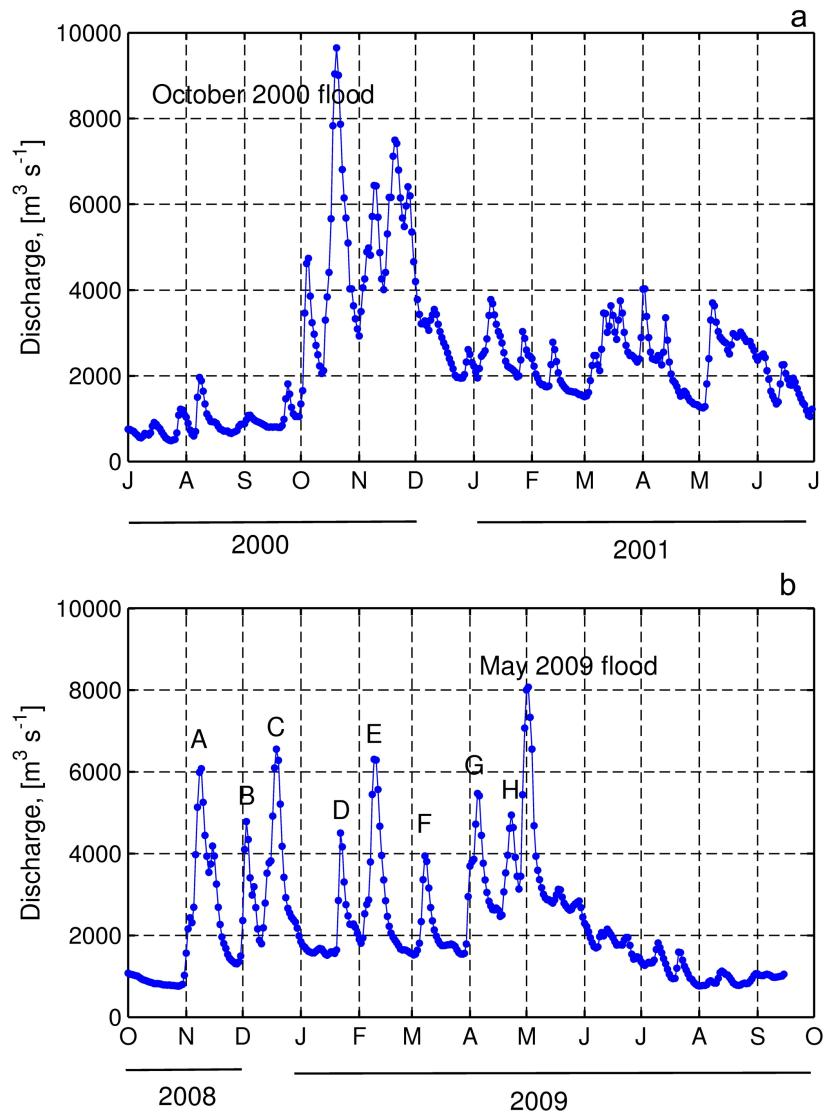

Fig. 2. (a) Po river discharge at Pontelagoscuro station from June 2000 through July 2001. (b) 1-yr Po river discharge at Pontelagoscuro station from October 2008 through October 2009.

released because of the temperature rising since mid-April. At the end of April, heavy precipitation occurred in the Po watershed, mainly in the western portion of the drainage basin. The co-occurrence of rainfall and snowmelt resulted in increasing the river flow that reached the peak on 1 and 2 May (Fig. 2b).

Figure 2 shows the Po river discharge at Pontelagoscuro gauging station from June 2000 through June 2001 and from October 2008 through October 2009. Although inferior to the October 2000 flood, the May 2009 event was significant reaching over $8000 \mathrm{~m}^{3} \mathrm{~s}^{-1}$ (Fig. 2b). These two floods exhibited interesting contrasts and similarities. First of all, these floods occurred during different seasons and were triggered by different events (i.e. rainfall for the October 2000 flood whereas combination of snowmelt and rainfall for the May 2009 flood). Then, whereas the October 2000 flood was a discrete event (Fig. 2a), the May 2009 flood occurred at the end of a long rainy period. As a result, the May 2009 flood was preceded by at least 8 important events exceeding $4000 \mathrm{~m}^{3} \mathrm{~s}^{-1}$ (Fig. 2b). Concerning the similarities, the flood emplacement in May 2009 occurred during fair marine weather conditions (wave height $<1 \mathrm{~m}$ ) and relative small
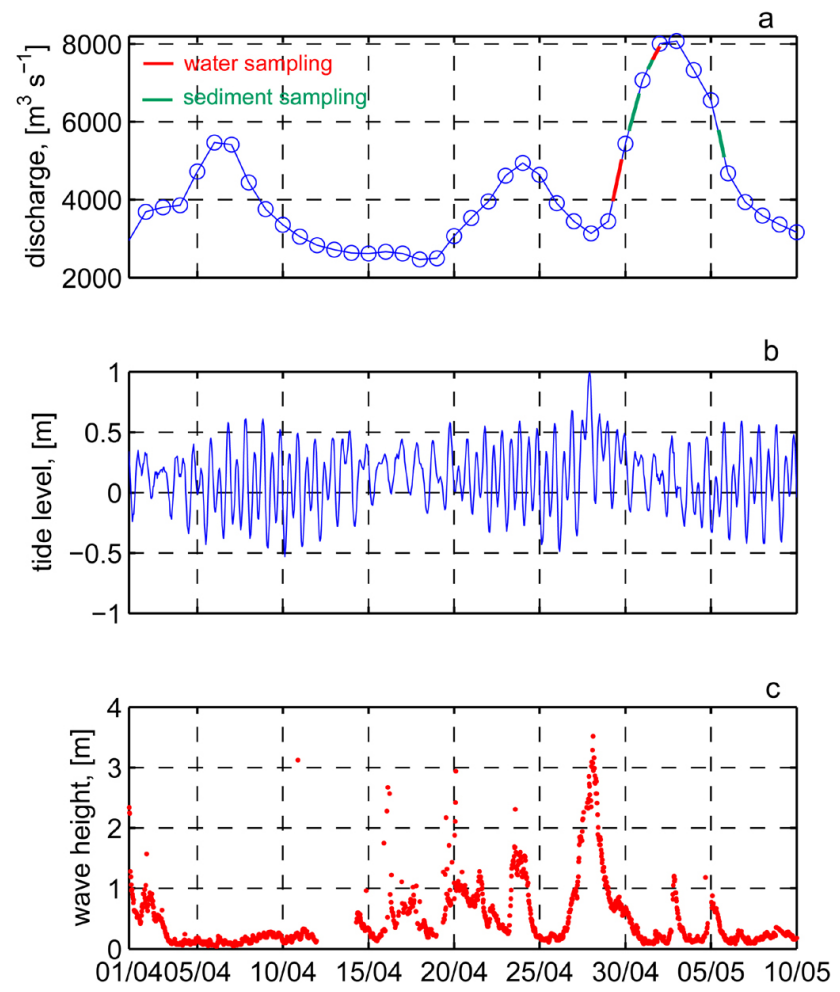

Fig. 3. Time-series data from 1 April through 10 May 2009. (a) River discharge during sampling in the prodelta. (b) Tide level. (c) Wave height.

tide oscillations ( $\sim 50 \mathrm{~cm})$ (Fig. 3b, c) suggesting deposition in shallow regions of the prodelta as observed for October 2000 flood (Wheatcroft et al., 2006).

\section{Methods}

\subsection{Sampling}

\subsubsection{Suspended material of the Po river}

Suspended sediments from the Po river were collected on 23 April 2009 at Pontelagoscuro gauging station during a peak in water discharge $\left(\sim 5000 \mathrm{~m}^{3} \mathrm{~s}^{-1}, \mathrm{H}\right.$ event in Fig. $\left.2 \mathrm{~b}\right)$. Samples were collected from a road bridge in three different locations, at the left, center, and right relative to the river axis. Three subsamples $(50 \mathrm{ml})$ from each sample $(25 \mathrm{l})$ were filtered on pre-combusted and pre-weighed GF/F filters $\left(0.7 \mu \mathrm{m}\right.$ mesh). Filters were oven-dried $\left(50^{\circ} \mathrm{C}\right)$ for $24 \mathrm{~h}$ and weighed to determine suspended sediment concentration (SSC, $\mathrm{mg} \mathrm{l}^{-1}$ ). Subsequently, remaining water samples were filtered with a $63 \mu \mathrm{m}$ mesh. The fraction $>63 \mu \mathrm{m}$ was placed in the oven $\left(50{ }^{\circ} \mathrm{C}\right)$ and then weighed to calculate the coarse fraction. The remaining water samples $(<63 \mu \mathrm{m})$ were placed in the dark at $3{ }^{\circ} \mathrm{C}$ for 3 days until complete settling of particles. The supernatant was removed and a 
subsample was filtered on precombusted GF/F filter to estimate the remaining material in suspension. This latter fraction was less than $1 \%$ relative to the SSC for each sample. The fraction $<63 \mu \mathrm{m}$ was transferred into plastic tubes and centrifugated. The supernatant was removed and tubes were placed in the oven $\left(50^{\circ} \mathrm{C}\right)$. Both coarse and fine fractions were ground and used for organic carbon (OC), total nitrogen $(\mathrm{TN})$, and $\mathrm{OC}$ stable isotope $\left(\delta^{13} \mathrm{C}\right)$, and biomarker analyses.

\subsubsection{Suspended material in the Po prodelta}

Because of the distance between Pontelagoscuro gauging station and the coast, the time elapsed for the water to reach the sea must be taken into account $(\sim 10 \mathrm{~h}$ assuming a mean current speed of $2.5 \mathrm{~m} \mathrm{~s}^{-1}$ during floods (Burnelli et al., 2006) and the distance of $\sim 90 \mathrm{~km}$ from the gauging station to the coast) Throughout the text, discharge data always refer to the theoretical value calculated adding $10 \mathrm{~h}$ to the discharge measured at Pontelagoscuro gauging station.

Suspended materials in the Po prodelta were collected early in the event under conditions of moderate river flow on 29 April $\left(\sim 4500 \mathrm{~m}^{3} \mathrm{~s}^{-1}\right)$ and $24 \mathrm{~h}$ later during the peak discharge on 1 May $2009\left(\sim 8000 \mathrm{~m}^{3} \mathrm{~s}^{-1}\right)$ (Fig. 3a). Surface and bottom water samples were collected on the R/V Urania using a CTD Rosette systems equipped with Niskin bottles. At each station, continuous profiles of salinity, transmittance, and fluorescence were obtained using a Sea-Bird CTD profiler (Mod. SBE 911 plus). Surface and bottom water samples were sampled at $\sim 1 \mathrm{~m}$ below sea surface and $\sim 2 \mathrm{~m}$ above seabed, respectively. Water samples were filtered on pre-combusted and pre-weighed GF/F filters (two replicates) and Isopore Membrane polycarbonate filters $(0.4 \mu \mathrm{m}$ mesh, $142 \mathrm{~mm}$ diameter) (Tramontano and Church, 1984). GF/F filters were rinsed with MilliQ water and oven-dried $\left(50^{\circ} \mathrm{C}\right)$ on ship. GF/F filters were used for SSC, organic carbon (OC), total nitrogen (TN), and carbon stable isotope analyses $\left(\delta^{13} \mathrm{C}\right)$. Polycarbonate filters were placed in large plastic tubes with $50 \mathrm{ml}$ of filtered seawater. Tubes were capped and vigorously shaken until complete detachment of material from the filter. Filters were then rinsed with filtered seawater and removed from the tube. Tubes were centrifuged, the supernatant removed with a syringe and the recovered sediment was oven-dried $\left(50^{\circ} \mathrm{C}\right)$ on ship. Once dry, samples were grind for biomarker analyses. An aliquot of unfiltered suspended material was used for grain-size analyses.

\subsubsection{Sediment cores}

During the EuroSTRATAFORM project (Palinkas et al., 2005; Wheatcroft et al., 2006; Miserocchi et al., 2007), sediment cores were collected in 33 sites from the Po prodelta to describe the initial emplacement of deposits from the October 2000 flood. In this study, 10 of these stations were re-occupied to be consistent with previous publications.
Sediment cores were collected before and after the peak discharge. The first set of samples Was collected on 30 April and 1 May when the flow ranged from $\sim 6000$ to $\sim 7000 \mathrm{~m}^{3} \mathrm{~s}^{-1}$ (Fig. 3a). The second set of samples were collected on 5 May when the discharge had dropped to $\sim 5000 \mathrm{~m}^{3} \mathrm{~s}^{-1}$. Sediment cores were collected using a box-corer. On deck, sediments were sub-sampled for xradiographs, biogeochemical, and ${ }^{7} \mathrm{Be}$ analyses using slabs and PVC tubes. Samples for X-radiographs and biogeochemical analyses were placed in the dark at $3{ }^{\circ} \mathrm{C}$. On board, sediment cores for radioisotope analyses were extruded, subsampled at $1 \mathrm{~cm}$ interval, and placed in the oven. In the laboratory, rectangular containers were $\mathrm{x}$-radiographed and then sub-sampled at $1 \mathrm{~cm}$ intervals for biogeochemical analyses. Samples were then oven-dried $\left(50^{\circ} \mathrm{C}\right)$.

\subsection{Analyses}

\subsubsection{SSC, OC, TN, and $\delta^{13} \mathrm{C}$}

SSC, OC, TN, and $\delta^{13} \mathrm{C}$ were calculated as the average of two replicates for each sample. In the laboratory, preweighed $\mathrm{GF} / \mathrm{F}$ filters were oven-dried $\left(50^{\circ} \mathrm{C}\right)$ to ensure complete removal of moisture. Two filters for each sample were then weighed to calculate the total suspended matter (SSC, $\mathrm{mg} \mathrm{L}^{-1}$ ). Linear regression was used to convert transmittance data in SSC values. However, because during the peak discharge the transmissometer reached the bottom of the scale $(0 \%)$, SSC and transmittance do not exhibit a robust relationship.

$\mathrm{OC}, \mathrm{TN}$, and $\delta^{13} \mathrm{C}$ analyses were carried out on acidified $\mathrm{GF} / \mathrm{F}$ filters and sediment samples $(\mathrm{HCl}, 10 \%)$ to remove the carbonate fraction. Analyses were performed using a Thermo Electron DeltaPlus XP mass spectrometer directly interfaced to a Costech ECS4010 Elemental Analyzer via a Conflo III. The internal standards for isotopic measurements were apple leaves (NIST 1515) and the error for replicate analyses of the standard was $\pm 0.05 \%$. OC and $\mathrm{TN}$ values are reported as weight percent (wt\%) whereas stable isotope data are expressed in the conventional delta notation $(\delta)$.

\subsubsection{Terrigenous biomarkers}

Alkaline $\mathrm{CuO}$ oxidations were carried out using a Microwave digestion system according to the procedure described in Goñi and Montgomery (2000). Dry samples were placed in teflon vessels with $15 \mathrm{ml}$ of alkaline solution $(2 \mathrm{~N} \mathrm{NaOH})$, $500 \mathrm{mg}$ of $\mathrm{CuO}, 50 \mathrm{mg}$ of $\mathrm{Fe}\left(\mathrm{NH}_{4}\right)_{2}\left(\mathrm{SO}_{4}\right)_{2} \cdot 6 \mathrm{H}_{2} \mathrm{O}$ and oxidized for $1.5 \mathrm{~h}$ at $150^{\circ} \mathrm{C}$. Once the oxidation was complete, a known amount of recovery standards (ethylvanillin and trans-cinnamic acid) was added to each vessel and acidified to $\mathrm{pH} 1$ with $\mathrm{HCl}$. Reaction products were extracted with ethylacetate and then evaporated to dryness under $\mathrm{N}_{2}$. Once the solvent was evaporated, samples were redissolved in pyridine. Terrestrial OC yields a suite of lignin 
reaction products including vanillyl phenols (V-series), syringyl phenols (S-series), and cinnamyl phenols (C-series). Throughout the text, $\Lambda$ refers to the carbon-normalized sum of lignin phenols $(\mathrm{V}+\mathrm{S}+\mathrm{C})$. Reaction products were analyzed as trimethylsilyl derivatives (BSTFA reagent) by gas chromatography (GC) using a Hewlett-Packard 5980. The yields of individual lignin and non-lignin oxidation products were quantified by GC-MS using selective ion monitoring. The compounds were separated chromatographically in a $30 \mathrm{~m} \times 250 \mu \mathrm{m}$ DB1 $(0.25 \mu \mathrm{m}$ film thickness $)$ capillary GC column, using an initial temperature of $100^{\circ} \mathrm{C}$, a temperature ramp of $4{ }^{\circ} \mathrm{C} \mathrm{min}^{-1}$ and a final temperature of $300^{\circ} \mathrm{C}$. Phenol biomarkers were quantified using the response factors of commercially available standards (Goñi et al., 1998).

\subsubsection{Surface area, sediment texture, and coulter counter data}

Approximately $5 \mathrm{~g}$ of unground, salt-free sediment samples were combusted at $400^{\circ} \mathrm{C}$ for $3 \mathrm{~h}$ to remove organic matter. The surface area of sediment samples were determined by nitrogen adsorption, using a 5-points BET method (Mayer, 1994). About $1 \mathrm{~g}$ of pre-treated sediment was degassed at $300^{\circ} \mathrm{C}$ in the vacuum station to ensure complete removal of moisture prior to analysis on Micromeritics surface area analyzer TriStar 3000. Data are reported as $\mathrm{m}^{2} \mathrm{~g}^{-1}$ sediment. The remaining OC-free sediment samples were used for grain-size analysis. Samples were dispersed in sodium metaphosphate and then sieved with a $125 \mu \mathrm{m}$ prior to analysis on Micromeritics SediGraph 5120. Data are shown as median value in $\mu \mathrm{m}\left(D_{50}\right)$ and relative contribution to dry weight for clay $(<3.9 \mu \mathrm{m})$, silt $(3.9-62.5 \mu \mathrm{m})$, and fine sand $(62.5-125 \mu \mathrm{m})$. Suspended samples for particle concentration and grain size spectrum were processed on board, immediately after sampling, using a Multisizer 3 Coulter Counter, equipped with a $100-\mu \mathrm{m}$ aperture tube, sizing particles from 2 to $60 \mu \mathrm{m}$ in diameter. Data are shown as grain size spectra and median value $\left(D_{50}\right)$ in $\mu \mathrm{m}$.

\subsection{4 ${ }^{7} \mathrm{Be}$}

Dried samples were slightly disaggregated, then put in plastic jars and counted by gamma spectrometry in an identical counting geometry. Gamma emissions were counted at $477.7 \mathrm{keV}$ photopeak for approximately $24 \mathrm{~h}$ using Ortec germanium detectors which were calibrated with commercially available standard. Activities were then decay-corrected to the time of collection.

\subsubsection{Biogenic opal}

Biogenic opal $\left(\mathrm{SiO}_{2} \cdot n \mathrm{H}_{2} \mathrm{O}\right)$ content was measured in sediment samples according to the procedure described in Demaster (1981). About $90 \mathrm{mg}$ of sediments were placed in Teflon tubes. Alkaline dissolution was performed with $40 \mathrm{ml}$
$0.5 \mathrm{M} \mathrm{Na}_{2} \mathrm{CO}_{3}$ solution at $80^{\circ} \mathrm{C}$ for $5 \mathrm{~h}$. At known intervals, Teflon tubes were centrifuged and the supernatant was sub-sampled $(200 \mu \mathrm{l})$. Dissolved silica was then measured with the molybdate-blue spectrophotometric method (wave length $812 \mathrm{~nm}$ ). Dissolution kinetic of quartz is lower relative to biogenic opal dissolution although it might increase the concentration of silicic acid in the supernatant with time. Therefore, the intercept of the regression line between time $(x)$ and silica concentration $(y)$ was considered as the actual biogenic opal content (Mortlock and Froelich, 1989). Data are reported as weight percent (wt\%) of $\mathrm{SiO}_{2}$.

\subsubsection{Radiocarbon measurements}

Radiocarbon analyses were performed at the National Ocean Sciences Accelerator Mass Spectrometry Facility (NOSAMS, Woods Hole Oceanographic Institution). The $\mathrm{CO}_{2}$ samples were obtained by the combustion of bulk OC from pre-acidified samples to remove the inorganic fraction. The gas was then purified cryogenically and converted to graphite using hydrogen reduction with an iron catalyst. The graphite was pressed into targets, which were analyzed on the accelerator along with standards and process blanks. Oxalic Acid II (NIST-SRM-4990C) was the primary standard used for all ${ }^{14} \mathrm{C}$ measurements. Radiocarbon measurements results are reported as $\triangle 14 \mathrm{C}(\%)$.

\subsection{Statistical analysis}

Differences between groups were performed using a twotailed unpaired t-test. Alpha levels were set to 0.05 (significant) and 0.01 (highly significant). $P$ values are reported throughout the text when difference are statistically significant.

\section{Results}

\subsection{Po river suspended matter}

Results for river samples are listed in Tables 1 and 2. Most of the sediment load in the river was associated with the fine fraction $(<63 \mu \mathrm{m})$ accounting for over $97 \%$ of the SSC. Coarse and fine fractions exhibited contrasting compositions statistically significant $(p<0.01)$ in both bulk and biomarker parameters. On average, the coarse fraction showed higher $\mathrm{OC}$ and TN contents, relatively depleted $\delta^{13} \mathrm{C}$ values, and higher OC:TN ratios. Fine material was less rich in $\mathrm{OC}$ and $\mathrm{TN}$, isotopically enriched, and depleted in OC relative to TN compared to the coarse fraction. Radiocarbon measurements were carried out only on samples collected in the center of the river. $\Delta^{14} \mathrm{C}$ of the fine fraction was significantly more depleted than the coarse material. All carbon-normalized lignin-derived products (i.e., syringyl, vanillyl, and cinnamyl phenols) were more abundant in the coarse fraction relative 
Table 1. Po river samples collected at Pontelagoscuro (PLS).

\begin{tabular}{llr|rr|rr|rr|c}
\hline \multirow{2}{*}{ Sample } & SSC & OC & TN & OC & TN & $\delta^{13} \mathrm{C}$ & $\Delta^{14} \mathrm{C}$ & OC:TN \\
\cline { 3 - 8 } & & {$\left[\mathrm{mg} \mathrm{l}^{-1}\right]$} & \multicolumn{2}{c}{$[\mathrm{wt} \%]$} & {$\left[\mu \mathrm{g} \mathrm{L}^{-1}\right]$} & {$[\%$ ] } & [ratio] \\
\hline PLS right & coarse, $>63 \mu \mathrm{m}$ & 8.8 & 3.6 & 0.26 & 316.9 & 23.1 & -27.1 & & 13.7 \\
PLS center & coarse, $>63 \mu \mathrm{m}$ & 8.7 & 4.2 & 0.31 & 365.6 & 26.7 & -27.0 & -46.1 & 13.7 \\
PLS left & coarse, $>63 \mu \mathrm{m}$ & 4.2 & 4.8 & 0.35 & 203.8 & 14.9 & -27.1 & & 13.7 \\
& average & 7.2 & 4.2 & 0.31 & 295.4 & 21.6 & -27.1 & & 13.7 \\
& s.d. & 2.6 & 0.6 & 0.04 & 83.0 & 6.1 & 0.1 & & 0.0 \\
PLS right & fine, $<63 \mu \mathrm{m}$ & 439.2 & 1.3 & 0.14 & 5501.8 & 633.0 & -26.0 & & 8.7 \\
PLS center & fine, $<63 \mu \mathrm{m}$ & 465.4 & 1.1 & 0.15 & 5280.6 & 687.4 & -25.6 & -241 & 7.7 \\
PLS left & fine, $<63 \mu \mathrm{m}$ & 417.9 & 1.1 & 0.14 & 4738.5 & 601.4 & -25.7 & & 7.9 \\
& average & 440.8 & 1.2 & 0.15 & 5173.6 & 640.6 & -25.8 & & 8.1 \\
& s.d. & 23.8 & 0.1 & 0.01 & 392.7 & 43.5 & 0.2 & & 0.5 \\
\hline
\end{tabular}

Table 2. Lignin biomarkers of Po river suspended samples collected at Pontelagoscuro (PLS).

\begin{tabular}{llllll|llll}
\hline \multirow{2}{*}{ Sample } & $\mathrm{S}$ & $\mathrm{V}$ & $\mathrm{C}$ & $\Lambda$ & $\mathrm{C}: \mathrm{V}$ & $\mathrm{S}: \mathrm{V}$ & $\mathrm{Vd}: \mathrm{Vl}$ & $\mathrm{Sd}: \mathrm{Sl}$ \\
\cline { 3 - 10 } & & \multicolumn{3}{c}{$\left[\mathrm{mg} \mathrm{100} \mathrm{mg}^{-1} \mathrm{OC}\right]$} & \multicolumn{5}{c}{ [ratio] } \\
\hline PLS right & coarse, $>63 \mu \mathrm{m}$ & 2.75 & 2.58 & 0.70 & 6.02 & 0.27 & 1.07 & 0.55 & 0.52 \\
PLS center & coarse, $>63 \mu \mathrm{m}$ & 2.69 & 2.89 & 0.71 & 6.29 & 0.25 & 0.93 & 0.58 & 0.53 \\
PLS left & coarse, $>63 \mu \mathrm{m}$ & 2.52 & 2.44 & 0.32 & 5.29 & 0.13 & 1.03 & 0.60 & 0.57 \\
& average & 2.65 & 2.64 & 0.58 & 5.87 & 0.22 & 1.01 & 0.58 & 0.54 \\
& s.d. & 0.12 & 0.23 & 0.22 & 0.52 & 0.07 & 0.07 & 0.03 & 0.03 \\
PLS right & fine, $<63 \mu \mathrm{m}$ & 0.69 & 0.63 & 0.20 & 1.51 & 0.31 & 1.10 & 0.76 & 0.67 \\
PLS center & fine, $<63 \mu \mathrm{m}$ & 0.72 & 0.70 & 0.26 & 1.68 & 0.38 & 1.03 & 1.27 & 1.23 \\
PLS left & fine, $<63 \mu \mathrm{m}$ & 0.83 & 0.68 & 0.26 & 1.77 & 0.38 & 1.23 & 1.10 & 0.78 \\
& average & 0.75 & 0.67 & 0.24 & 1.66 & 0.36 & 1.12 & 1.05 & 0.89 \\
& s.d. & 0.07 & 0.04 & 0.04 & 0.13 & 0.04 & 0.10 & 0.26 & 0.30 \\
\hline
\end{tabular}

to the fine material ( $p<0.01$ ). The cinnamyl to vanillyl phenols ratio $([\mathrm{C}: \mathrm{V}])$ and the syringyl to vanillyl phenols ratio $([\mathrm{S}: \mathrm{V}])$ have been used in several biogeochemical studies to infer the origin of terrigenous tissues (e.g., angiosperm, gymnosperm, woody, and grass tissue) (Hedges and Mann, 1979; Hedges et al., 1986; Goñi et al., 1998; Gordon and Goñi, 2003; Goñi et al., 2008). In addition, the acid to aldehyde ratios of vanillyl ([Vd:Vl]) and syringyl ([Sd:Sl]) phenols provide additional details concerning the degradative stage of terrigenous OC (Opsahl and Benner, 1995; Onstad et al., 2000; Gordon and Goñi, 2003; Goñi et al., 2008). Only the $[\mathrm{C}: \mathrm{V}]$ and $[\mathrm{Vd}: \mathrm{Vl}]$ ratios exhibited significant differences between coarse and fine materials $(p<0.05)$. ${ }^{7} \mathrm{Be}$ was measured and detected in all fine materials whereas coarse fractions were too scarce for radioisotope analyses.

\subsection{Water column in the Po prodelta}

Results for the water column are shown in Figs. 4 and 5 and Tables 3 and 4. Samples were grouped according to latitude in three sub-regions: north, central, and south. The northern region is under the influence of Pila outlet whereas the central and southern prodelta are affected by Tolle and Gnocca/Goro distributary, respectively. During moderate discharge, when the flow was $\sim 5000 \mathrm{~m}^{3} \mathrm{~s}^{-1}$, salinity, transmittance and SSC values showed weak evidence of plume intrusion (Table 3; Figs. 5, 6). In surface waters, the highest SSC and lowest transmittance values were observed in the northern prodelta under the influence of the Pila distributary (Fig. 3; Tables 4, 5). Conversely, resuspension dominated in both the center and southern prodelta areas where bottom waters exhibited low transmittance and relatively high SSC values likely as result of the storm event that occurred the day before sampling (wave height $>3 \mathrm{~m}$ ) (Fig. 3c). This 

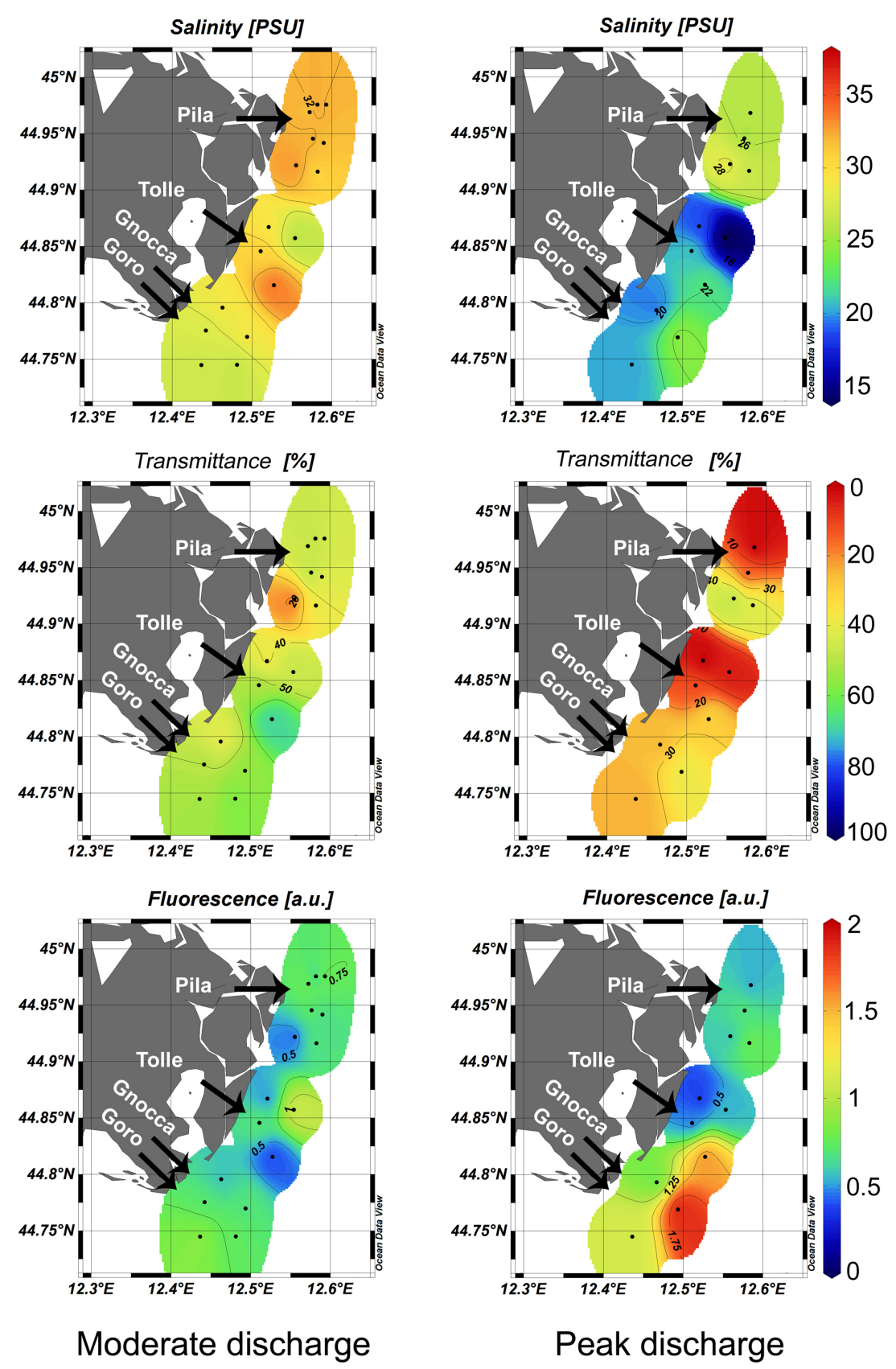

Fig. 4. Salinity, transmittance, and fluorescence in the Po prodelta in surface waters (1 $\mathrm{m}$ below the sea surface) during moderate $\left(\sim 5000 \mathrm{~m}^{3} \mathrm{~s}^{-1}\right)$ and peak discharge $\left(\sim 8000 \mathrm{~m}^{3} \mathrm{~s}^{-1}\right)$.

turbid nepheloid layer was measured several meters above the seafloor (Fig. 5) and was characterized by a fine sediment texture (Table 3). During the peak of the flood when the discharge reached $\sim 8000 \mathrm{~m}^{3} \mathrm{~s}^{-1}$, surface waters exhibited an overall decrease in salinity and transmittance values as well as an increase in the SSC values, in particular next to the river outlets in the northern and central prodelta $(\mathrm{E}$ and $\mathrm{J}$ transects in Fig. 1, respectively). As a result, all aforementioned parameters exhibited statistically significant dif- ferences $(p<0.05)$ between moderate and peak discharge in all sub-regions, except for the sediment texture. Although the influence of the flood was observed in all sub-regions, the southern prodelta exhibited a relatively modest increase in SSC values (max value at $\mathrm{P} 15$ station, $5.7 \mathrm{mg} \mathrm{L}^{-1}$ ). The rest of the prodelta exhibited a significant increase in the SSC values, especially just off Pila (E16 station, $53.1 \mathrm{mg} \mathrm{L}^{-1}$ ) and Tolle (J13 station, $26.5 \mathrm{mg} \mathrm{L}^{-1}$ ) mouths in the northern and central prodelta, respectively (see Fig. 1 for site locations). 


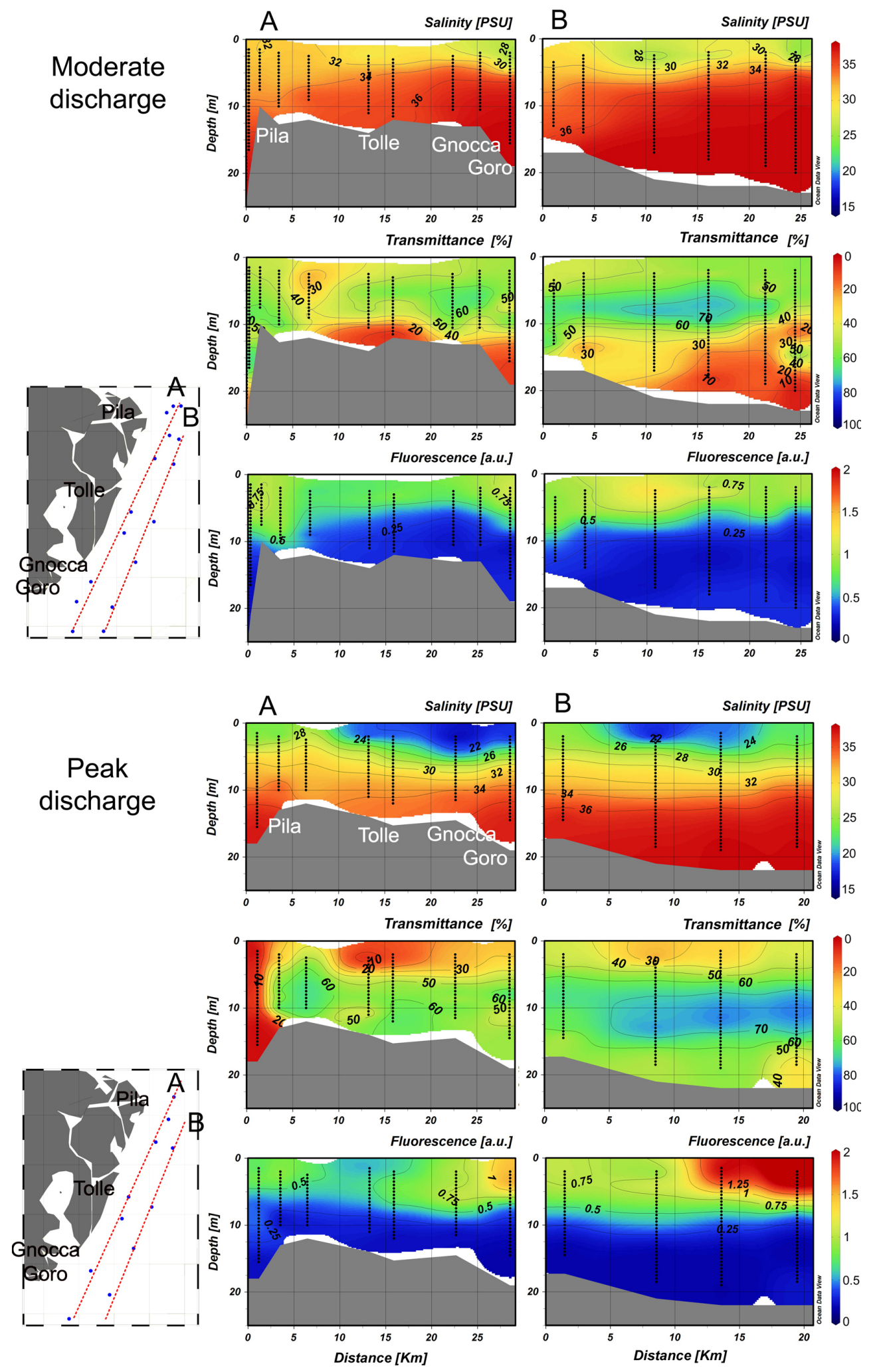

Fig. 5. Salinity, transmittance, and fluorescence in the Po prodelta along two shore-parallel sections during moderate $\left(\sim 5000 \mathrm{~m}^{3} \mathrm{~s}^{-1}\right)$ and peak discharge $\left(\sim 8000 \mathrm{~m}^{3} \mathrm{~s}^{-1}\right)$. 
Conversely, the highest fluorescence values $(p<0.01)$ were observed in the southern area in both river discharge conditions, in particular during the peak of the flow (Table 3 and Fig. 6).

In the suspended material, the weight percent (wt\%) of OC and TN exhibited a broad range of values, ranging from 1.7 to $11.7 \%$ and from 0.24 to $2.26 \%$ for OC and TN, respectively. The highest $\mathrm{OC}$ and $\mathrm{TN}$ concentrations were mainly measured during moderate flow far from distributary mouths. No statistically significant differences were observed in the elemental compositions between moderate and peak discharge (Table 4). However, because of high sediment concentrations during the peak of the flow, surface waters exhibited higher concentrations of $\mathrm{OC}$ and TN per liter $\left(\mu \mathrm{g} \mathrm{L}^{-1}\right)$ relative to the moderate discharge condition $(p<0.01) . \quad \delta^{13} \mathrm{C}$ did not exhibit a clear spatial distribution in the prodelta and no statistically significant differences were observed between sampling periods. Lignin phenols were measured in all suspended samples, although their concentrations showed

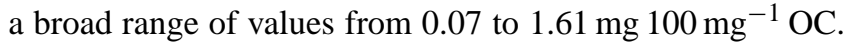
Differences in the concentration of lignin phenols were observed between moderate and peak discharge $(p<0.05)$ in surface waters (Table 4 ). The highest $\Lambda$ values were measured during the peak of the flow just off Pila (E transect) and Tolle ( $\mathrm{J}$ transect) mouths, which is consistent with the SSC values.

\subsection{Sediment cores}

${ }^{7} \mathrm{Be}$ data and radiographs for sediment cores collected in the Po prodelta are shown in Table 5 and Fig. 6. Samples were grouped based on the date of collection. Thickness of the October 2000 flood (Wheatcroft et al., 2006) is included in Table 5 for comparison. Most of the cores collected before the peak of the flood did not show any clear evidence of recent sediment deposition (Fig. 6). ${ }^{7} \mathrm{Be}$ penetrations were relatively modest and most of the cores were bioturbated. Only samples collected off the Pila mouth (E transect) showed significant ${ }^{7} \mathrm{Be}$ penetrations $(1$ to $10 \mathrm{~cm}$ ), suggesting recent deposition attributable to the late April-early May flood or, alternatively, to previous events. Unfortunately, ${ }^{7} \mathrm{Be}$ is not sufficient to exactly assess when accumulation occurred as this radionuclide is theoretically detectable up to $\sim 200$ days since sediment emplacement. ${ }^{7} \mathrm{Be}$ penetrations in the central prodelta ( $\mathrm{J}$ and $\mathrm{H}$ transects) were extremely low $(1-2 \mathrm{~cm})$, particularly evident when these estimates are compared to the October 2000 flood thicknesses (Table 5). In the southern prodelta, ${ }^{7} \mathrm{Be}$ was not detected as at the N14 station.

Stations under the influence of Pila and Tolle distributaries have been reoccupied after the peak discharge on 5 May 2009. These two sites exhibited among the highest SSC and lowest transmittance values measured in surface waters on 1 May 2009 during the peak of the flood (Fig. 4). Radiographs indicated thick event strata up to 17 and $6 \mathrm{~cm}$ for E16-II (Pila) and J13-II (Tolle), respectively (Fig. 6). Com-

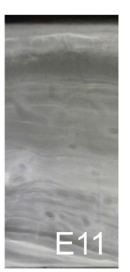

30-April
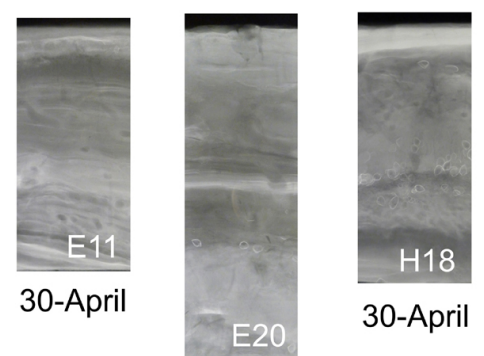

30-April

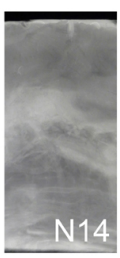

30-April

30-April
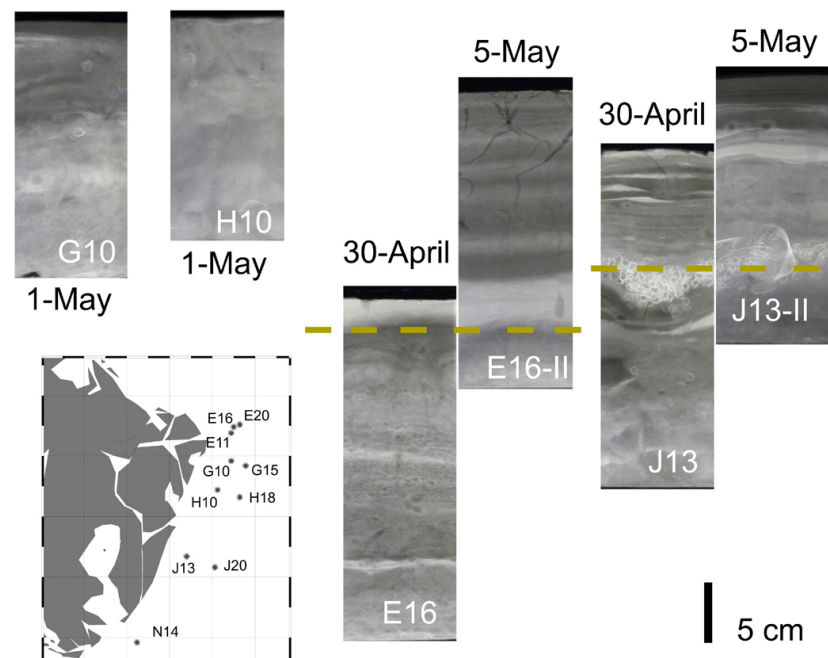

Fig. 6. Radiographs of sediment cores collected in Po prodelta in 30 April, 1 May, and 5 May.

paring ${ }^{7}$ Be penetrations and radiographs before and after the peak discharge, the emplacement of these event strata are undoubtedly the result of the May 2009 flood. Both flood deposits are characterized by coarse basal strata wherein ${ }^{7} \mathrm{Be}$ was not detected, probably as a result of preferential adsorption of the radionuclide on fine fractions. Active bioturbation was noticed during the subsampling of the E16-II core and it was then confirmed by the radiograph; however, most of the strata were preserved. Both sediment cores collected after the peak of the flood on 5 May (E16-II and J13-II cores) were used to characterize the OC deposition as result of the May 2009 flood. For this purpose, only event-strata belonging to the May 2009 event were analyzed and discussed in this study (first 17 and $6 \mathrm{~cm}$ for E16-II and J13-II, respectively).

Although event-strata collected in the northern and central prodelta are the result of the same flood event, E16-II and J13-II cores exhibited significant differences in several parameters. Among sedimentological variables, the E16-II core was significantly coarser and exhibited lower surface area compared to the J13-II core $(p<0.01)$ (Table 6). Concerning bulk biogeochemical parameters, statistically significant differences included the OC loading as well as the $\delta^{13} \mathrm{C}$ $(p<0.01)$ (Table 6). Specifically, E16-II showed a higher 
Table 3. Physical parameters for suspended sediment samples collected in the Po prodelta before and during the peak discharge.

\begin{tabular}{|c|c|c|c|c|c|c|c|c|}
\hline Discharge & Level & Channel & Location & $\begin{array}{l}\text { Salinity } \\
\text { [PSU] }\end{array}$ & $\begin{array}{c}\text { Transittance } \\
{[\%]}\end{array}$ & $\begin{array}{c}\text { Fluorescence } \\
\text { [a.u.] }\end{array}$ & $\begin{array}{c}\mathrm{SSC} \\
{\left[\mathrm{mg} \mathrm{L}^{-1}\right]}\end{array}$ & $\begin{array}{c}D_{50} \\
{[\mathrm{um}]}\end{array}$ \\
\hline \multirow{8}{*}{ 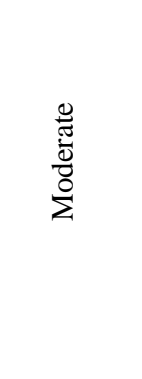 } & \multirow{4}{*}{ 。̊ } & Pila & North & $31.9 \pm 0.9$ & $41.0 \pm 13.3$ & $0.67 \pm 0.16$ & $5.0 \pm 2.9$ & $5.8 \pm 1.3$ \\
\hline & & Tolle & Center & $29.9 \pm 3.1$ & $51.8 \pm 13.3$ & $0.66 \pm 0.30$ & $2.7 \pm 1.4$ & $6.0 \pm 0.4$ \\
\hline & & Goro/Gnocca & South & $27.6 \pm 1.1$ & $51.7 \pm 6.14$ & $0.73 \pm 0.11$ & $2.9 \pm 0.3$ & $5.6 \pm 1.3$ \\
\hline & & & average top & $29.8 \pm 2.5$ & $47.7 \pm 11.6$ & $0.69 \pm 0.18$ & $3.8 \pm 2.2$ & $5.8 \pm 1.1$ \\
\hline & \multirow{4}{*}{$\begin{array}{l}\text { E } \\
\stackrel{0}{0} \\
\text { O } \\
\oplus\end{array}$} & Pila & North & $35.6 \pm 1.3$ & $43.7 \pm 28.6$ & $0.29 \pm 0.16$ & $4.6 \pm 2.1$ & $4.8 \pm 1.2$ \\
\hline & & Tolle & Center & $36.7 \pm 1.1$ & $12.2 \pm 18.9$ & $0.21 \pm 0.04$ & $7.6 \pm 4.1$ & $4.0 \pm 0.8$ \\
\hline & & Goro/Gnocca & South & $37.5 \pm 0.2$ & $21.1 \pm 24.1$ & $0.21 \pm 0.03$ & $6.0 \pm 2.9$ & $3.7 \pm 0.3$ \\
\hline & & & average bottom & $36.5 \pm 1.3$ & $28.7 \pm 27.4$ & $0.25 \pm 0.11$ & $5.5 \pm 3.4$ & $4.3 \pm 1.0$ \\
\hline \multirow{8}{*}{ है } & \multirow{3}{*}{ ô } & Pila & North & $25.6 \pm 0.8$ & $27.4 \pm 24.4$ & $0.64 \pm 0.10$ & $24.4 \pm 26.5$ & $6.3 \pm 2.3$ \\
\hline & & Tolle & Center & $17.5 \pm 4.5$ & $12.0 \pm 13.1$ & $0.73 \pm 0.57$ & $13.5 \pm 11.1$ & $4.9 \pm 0.3$ \\
\hline & & Goro/Gnocca & South & $21.3 \pm 2.6$ & $29.7 \pm 8.18$ & $1.25 \pm 0.58$ & $5.6 \pm 0.1$ & $5.2 \pm 0.6$ \\
\hline & \multirow{5}{*}{$\begin{array}{l}\Xi \\
\stackrel{0}{0} \\
0\end{array}$} & & average top & $21.5 \pm 4.5$ & $22.5 \pm 17.7$ & $0.84 \pm 0.49$ & $15.5 \pm 18.1$ & $5.6 \pm 1.5$ \\
\hline & & Pila & North & $35.8 \pm 2.1$ & $46.5 \pm 33.5$ & $0.14 \pm 0.02$ & $7.8 \pm 9.5$ & $5.4 \pm 2.0$ \\
\hline & & Tolle & Center & $36.1 \pm 1.8$ & $51.1 \pm 17.9$ & $0.13 \pm 0.04$ & $5.5 \pm 3.6$ & $4.8 \pm 1.6$ \\
\hline & & Goro/Gnocca & South & $36.8 \pm 1.1$ & $44.8 \pm 13.1$ & $0.14 \pm 0.04$ & $3.4 \pm 1.3$ & $3.8 \pm 0.5$ \\
\hline & & & average bottom & $36.2 \pm 1.6$ & $47.7 \pm 21.8$ & $0.14 \pm 0.03$ & $5.3 \pm 7.0$ & $4.7 \pm 1.5$ \\
\hline
\end{tabular}

Table 4. Bulk and biomarker composition for suspended sediment samples collected in the Po prodelta before and during the peak discharge.

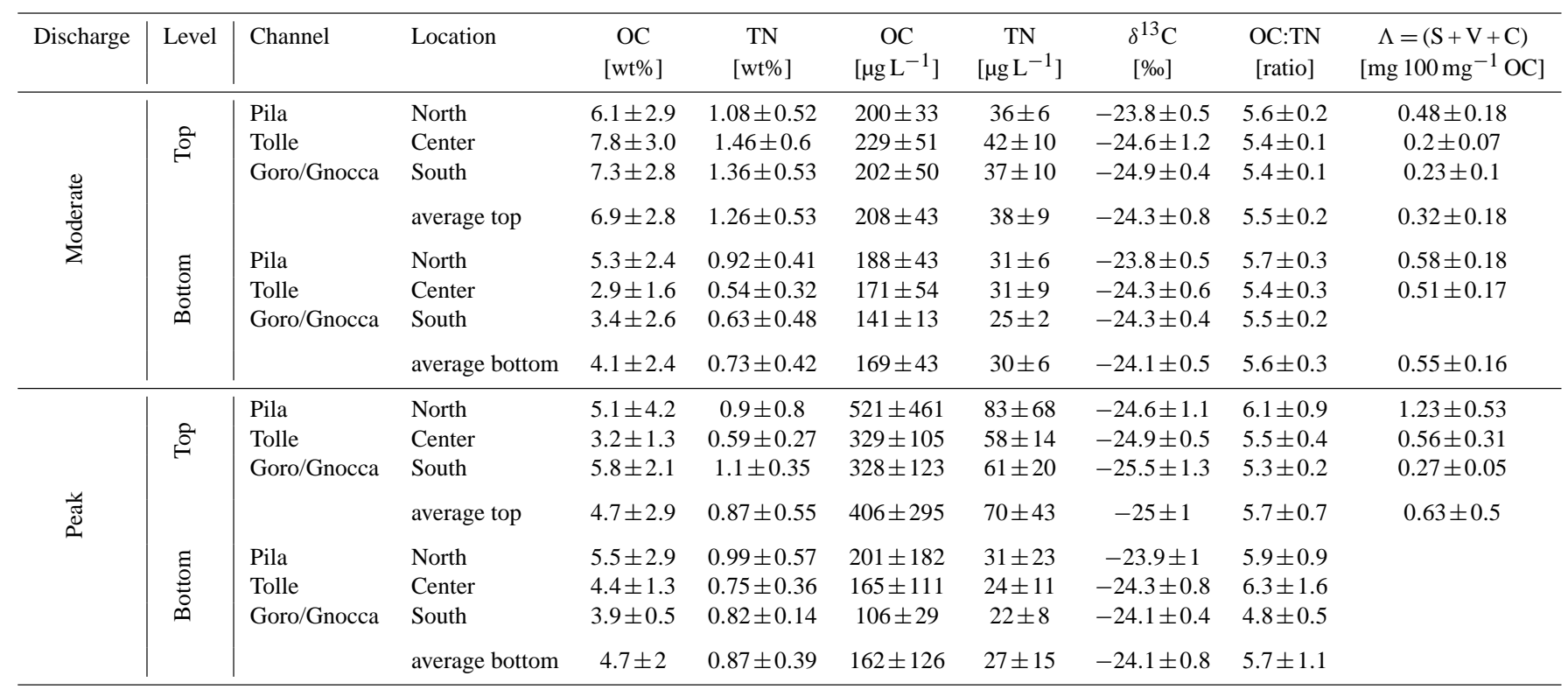

OC loading and more depleted $\delta^{13} \mathrm{C}$ values. Both cores exhibited an increase in the $\delta^{13} \mathrm{C}$ that coincided with the basal silty-sandy layer where ${ }^{7} \mathrm{Be}$ was not detected. Down-core profiles of $\Delta^{14} \mathrm{C}$ in both cores were relatively similar. In the upper core, $\Delta^{14} \mathrm{C}$ values were relatively enriched compared to the silty-sandy stratum where ${ }^{7} \mathrm{Be}$ was not detected. Sig- nificant differences $(p<0.001)$ were observed in the concentration of syringyl, vanillyl, and cinnamyl phenols, all of which were relatively more abundant in the E16-II core (Table 7). In spite of these differences in lignin contents, lignin-based parameters such as $[\mathrm{C}: \mathrm{V}],[\mathrm{S}: \mathrm{V}],[\mathrm{Sd}: \mathrm{Sl}]$, and [Vd:Vl] were fairly comparable between cores indicating 
Table 5. Penetrations of ${ }^{7} \mathrm{Be}$ in sediment cores collected in the Po prodelta before and after the peak discharge. Thicknesses of the October 2000 flood estimated via radiographs were shown as comparison.

\begin{tabular}{lllccccc}
\hline Collection date & Station & Delta Lobe & $\begin{array}{c}\text { Depth } \\
{[\mathrm{m}]}\end{array}$ & $\begin{array}{c}\text { Lat } \\
{\left[{ }^{\circ} \mathrm{N}\right]}\end{array}$ & $\begin{array}{c}\text { Long } \\
{\left[{ }^{\circ} \mathrm{E}\right]}\end{array}$ & $\begin{array}{c}{ }^{7} \text { Be penetration } \\
{[\mathrm{cm}]}\end{array}$ & $\begin{array}{c}\text { Oct-2000 } \\
\text { flood thickness* }{ }^{*}[\mathrm{~cm}]\end{array}$ \\
\hline Before the peak & & & & & & & \\
\hline 30 April 2009 & E11 & Pila & 12.0 & 44.970 & 12.575 & 10 & $\sim 36$ \\
30 April 2009 & E16 & Pila & 20.8 & 44.974 & 12.575 & 5 & $\sim 36$ \\
30 April 2009 & E20 & Pila & 15.0 & 44.975 & 12.582 & 1 & $\sim 36$ \\
30 April 2009 & H18 & Pila & 17.0 & 44.916 & 12.582 & 0 & $\sim 5$ \\
30 April 2009 & J13 & Tolle & 13.8 & 44.868 & 12.520 & 1 & $\sim 12$ \\
30 April 2009 & J20 & Tolle & 20.5 & 44.858 & 12.553 & 2 & $\sim 12$ \\
30 April 2009 & N14 & Goro/Gnocca & 12.0 & 44.796 & 12.462 & 0 & $\sim 8$ \\
1 May 2009 & G10 & Pila & 11.2 & 44.946 & 12.572 & 1 & $\sim 5$ \\
1 May 2009 & G15 & Pila & 15.9 & 44.942 & 12.589 & 2 & \\
1 May 2009 & H10 & Pila & 11.6 & 44.923 & 12.556 & 0 & $\sim 36$ \\
\hline After the peak & & & & & & & $\sim 25$ \\
\hline 5 May 2009 & E16-II & Pila & 16.3 & 44.974 & 12.576 & 17 & 5 \\
5 May 2009 & J13-II & Tolle & 14.1 & 44.868 & 12.521 & 5 & \\
\hline
\end{tabular}

* from Wheatcroft et al. (2006)

a terrigenous composition relatively homogeneous between northern and central prodelta.

Given that extremely low SSC were measured in the southern prodelta on 1 May despite the peak discharge, coring targets in this region were not re-occupied after the peak of the flood. However, the sediment core collected just off the Gnocca outlet (core N14, see Fig. 1) on 29 April was used as a stratigraphy record to characterize the event-driven supply of OC in the southern prodelta during the most rainy period of the last century that resulted in 8 distinct flood events (Fig. 2b). In addition to ${ }^{7} \mathrm{Be}$ and radiographs, bulk measurements were carried out on this core and they will be compared to biogeochemical compositions of a flood deposit collected at the same station two months after the peak of the October 2000 flood (Miserocchi et al., 2007). The N14 radiograph indicated a highly bioturbated sediment fabric with no evidence of layering and no detectable ${ }^{7} \mathrm{Be}$ (Table 5; Fig. 6). surface area down-core profile was relatively homogeneous, consistent with the bioturbated profile (Fig. 7). Only the major bulk measurements were carried out in this core. OC and TN contents were significantly lower than in event-strata collected in the same station after the October 2000 flood $(p<0.01)$. In addition, the $\delta^{13} \mathrm{C}$ that was isotopically heavier $(p<0.01)$ relative to the October 2000 deposit suggesting a different OC composition (Table 6).

\section{Discussion}

\subsection{Low, moderate and high discharge}

Based on seabed grain size distributions, Milligan et al. (2007) explained the particle settling from the Po plume as a function of the river discharge. During low-to-moderate flow conditions, sediment deposition is rapid and occurs within $2 \mathrm{~km}$ from the river mouth $(<10 \mathrm{~m}$ water depth). Such a rapid settling is caused by flocculation processes and relatively short floc residence time within the thin surface plume. Conversely, during high discharge levels, sediments are transported further into the prodelta because a thick plume increases the residence time of particles in the water column (i.e., sediment buoyancy).

In our study, the aforementioned conditions described by Milligan et al. (2007) were observed $24 \mathrm{~h}$ apart from each other (Figs. 4, 5). During the first survey on 29 April when the river flow was $\sim 5000 \mathrm{~m}^{3} \mathrm{~s}^{-1}$, SSC values in surface waters were relatively low (mean value $3.8 \pm 2.2 \mathrm{mg} \mathrm{L}^{-1}$, Table 3) and did not differ from SSC values measured by Boldrin et al. (2005) during dry periods (mean value 4.4 \pm $2.8 \mathrm{mg} \mathrm{L}^{-1}$ at $\sim 1000 \mathrm{~m}^{3} \mathrm{~s}^{-1}$, Boldrin et al., 2005). Indeed, the surface plume was relatively thin, whereas the highest SSC were observed in bottom waters $\left(5.5 \pm 3.4 \mathrm{mg} \mathrm{L}^{-1}\right.$, Table 3) because of the storm event occurred on 28 April (Fig. 5). During the second survey, when the river flow increased to $\sim 8000 \mathrm{~m}^{3} \mathrm{~s}^{-1}$, the turbid plume extended further into the central prodelta (Tolle region) and significant settling of sediment from the surface plume was observed near 
Table 6. Bulk compositions for sediment cores collected in the Po prodelta. See Fig. 1 for core locations.

\begin{tabular}{|c|c|c|c|c|c|c|c|}
\hline $\begin{array}{l}\text { Interval } \\
{[\mathrm{cm}]}\end{array}$ & $\begin{array}{c}\mathrm{OC} \\
{[\mathrm{wt} \%]}\end{array}$ & $\begin{array}{c}\mathrm{TN} \\
{[\mathrm{wt} \%]}\end{array}$ & $\begin{array}{r}\delta^{13} \mathrm{C} \\
{[\% o]}\end{array}$ & $\begin{array}{r}\Delta^{14} \mathrm{C} \\
{[\% o]}\end{array}$ & $\begin{array}{c}\text { OC:TN } \\
\text { [ratio] }\end{array}$ & $\begin{array}{c}\mathrm{SA} \\
{\left[\mathrm{m}^{2} \mathrm{~g}^{-1}\right]}\end{array}$ & $\begin{array}{r}D_{50} \\
{[\mu \mathrm{m}]}\end{array}$ \\
\hline \multicolumn{8}{|c|}{ Northern prodelta Flood deposit Core E16-II } \\
\hline $0-1$ & 1.3 & 0.14 & -27.0 & -204.8 & 8.69 & 13.2 & n.a. \\
\hline $1-2$ & 1.3 & 0.15 & -26.9 & & 8.51 & 13.9 & n.a. \\
\hline $2-3$ & 1.2 & 0.16 & -27.0 & 7.86 & 10.0 & 10.5 & \\
\hline $3-4$ & 1.0 & 0.12 & -26.7 & & 8.52 & 15.2 & 15.4 \\
\hline $4-5$ & 1.2 & 0.14 & -26.9 & & 8.84 & 14.9 & 9.0 \\
\hline $5-6$ & 0.9 & 0.10 & -26.9 & -176.7 & 8.59 & 12.8 & 10.6 \\
\hline $6-7$ & 1.2 & 0.13 & -27.1 & & 8.99 & 14.5 & 7.4 \\
\hline $7-8$ & 1.1 & 0.13 & -26.7 & & 8.55 & 12.7 & 9.7 \\
\hline $8-9$ & 1.2 & 0.14 & -26.9 & -193.7 & 8.63 & 11.6 & 7.4 \\
\hline $9-10$ & 1.2 & 0.15 & -26.4 & & 7.82 & 15.3 & 4.1 \\
\hline $10-11$ & 1.1 & 0.13 & -26.7 & & 8.47 & 13.4 & 6.5 \\
\hline $11-12$ & 1.2 & 0.12 & -26.9 & & 9.50 & 15.7 & 7.0 \\
\hline $12-13$ & 1.2 & 0.15 & -26.6 & & 8.08 & 15.9 & 4.7 \\
\hline $13-14$ & 0.9 & 0.12 & -26.3 & -222.3 & 7.57 & 14.8 & 4.7 \\
\hline $14-15$ & 0.5 & 0.07 & -26.1 & & 7.87 & 5.3 & 23.7 \\
\hline $15-16$ & 0.4 & 0.05 & -25.6 & & 7.02 & 4.5 & 29.4 \\
\hline $16-17$ & 0.5 & 0.07 & -25.8 & -339.4 & 7.35 & 5.0 & 23.5 \\
\hline average & 1.0 & 0.12 & -26.6 & -227.4 & 9.7 & 12.3 & 11.6 \\
\hline s.d. & 0.3 & 0.03 & 0.4 & 64.8 & 0.7 & 3.8 & 7.9 \\
\hline \multicolumn{8}{|c|}{ Central prodelta Flood deposit Core J13-II } \\
\hline $0-0.5$ & 1.2 & 0.15 & -26.3 & -204.1 & 7.63 & 27.1 & 2.0 \\
\hline $0.5-1$ & 1.3 & 0.16 & -26.3 & & 7.75 & 26.7 & 1.7 \\
\hline $1-2$ & 1.5 & 0.18 & -26.4 & -205.5 & 8.16 & 28.9 & 1.7 \\
\hline $2-3$ & 1.0 & 0.13 & -26.2 & & 7.83 & 20.6 & 2.9 \\
\hline $3-4$ & 1.3 & 0.15 & -26.1 & -207.6 & 8.32 & 22.0 & 2.0 \\
\hline $4-5$ & 0.8 & 0.10 & -24.6 & & 8.09 & 20.7 & 7.6 \\
\hline $5-6$ & 0.3 & 0.04 & -24.2 & -312.0 & 7.28 & 15.0 & 11.7 \\
\hline average & 1.0 & 0.13 & -25.7 & -232.3 & 9.2 & 23.0 & 4.2 \\
\hline s.d. & 0.4 & 0.05 & 0.9 & 53.2 & 0.4 & 4.9 & 3.9 \\
\hline \multicolumn{8}{|c|}{ Southern prodelta Bioturbated deposit Core N14 } \\
\hline $0-1$ & 0.61 & 0.09 & -24.85 & & 6.7 & 14.92 & n.a. \\
\hline $1-2$ & 0.70 & 0.08 & -25.23 & & 8.5 & 18.35 & n.a. \\
\hline $2-3$ & 0.69 & 0.08 & -25.29 & & 8.3 & 23.30 & n.a. \\
\hline $3-4$ & 0.79 & 0.09 & -25.33 & & 8.3 & 21.25 & n.a. \\
\hline $4-5$ & 0.76 & 0.09 & -25.46 & & 8.5 & 14.54 & n.a. \\
\hline $5-6$ & 0.51 & 0.06 & -25.01 & & 8.0 & 15.64 & n.a. \\
\hline $6-7$ & 0.40 & 0.05 & -24.94 & & 7.8 & 20.54 & n.a. \\
\hline $7-8$ & 0.46 & 0.06 & -25.1 & & 7.7 & 14.80 & n.a. \\
\hline $8-9$ & 0.63 & 0.08 & -25.38 & & 8.0 & n.a. & n.a. \\
\hline $9-10$ & 0.55 & 0.07 & -25.47 & & 7.4 & 16.52 & n.a. \\
\hline $10-11$ & 0.71 & 0.09 & -25.68 & & 8.1 & n.a. & n.a. \\
\hline $11-12$ & 0.54 & 0.07 & -25.44 & & 7.7 & n.a. & n.a. \\
\hline $12-13$ & 0.63 & 0.08 & -25.78 & & 7.5 & 22.73 & n.a. \\
\hline $13-14$ & 0.63 & 0.08 & -25.59 & & 7.8 & 27.68 & n.a. \\
\hline $14-15$ & 0.70 & 0.09 & -25.58 & & 8.0 & 17.26 & n.a. \\
\hline $15-16$ & 0.56 & 0.07 & -25.55 & & 7.6 & 16.01 & n.a. \\
\hline $16-17$ & 0.63 & 0.08 & -25.59 & & 8.1 & 15.09 & n.a. \\
\hline average & 0.6 & 0.08 & -25.4 & & 7.9 & 18.5 & \\
\hline s.d. & 0.1 & 0.01 & 0.3 & & 0.4 & 4.0 & \\
\hline
\end{tabular}

n.a. $=$ not available

the Pila mouth (Figs. 4, 5). Conversely, the southern prodelta under the influence of Goro/Gnocca outlets exhibited a relatively small increase in SSC despite the marked decrease in salinity (Table 2). Therefore, the combination of having low
Table 7. Lignin biomarkers for sediment cores collected in the Po prodelta after the May 2009 flood.

\begin{tabular}{|c|c|c|c|c|c|c|c|c|}
\hline \multirow{2}{*}{$\begin{array}{l}\text { Interval } \\
{[\mathrm{cm}]}\end{array}$} & $\mathrm{S}$ & $\mathrm{V}$ & $\mathrm{C}$ & $\Lambda$ & $\mathrm{C}: \mathrm{V}$ & $\mathrm{S}: \mathrm{V}$ & Vd:Vl & $\mathrm{Sd}: \mathrm{Sl}$ \\
\hline & \multicolumn{4}{|c|}{$\left[\mathrm{mg} 100 \mathrm{mg}^{-1} \mathrm{OC}\right]$} & \multicolumn{4}{|c|}{ [ratio] } \\
\hline \multicolumn{9}{|c|}{ Northern prodelta Flood deposit Core E16-II } \\
\hline $0-1$ & 1.25 & 1.22 & 0.38 & 2.85 & 0.31 & 1.03 & 0.35 & 0.37 \\
\hline $1-2$ & 1.36 & 1.31 & 0.39 & 3.06 & 0.30 & 1.04 & 0.41 & 0.40 \\
\hline $2-3$ & 1.39 & 1.32 & 0.40 & 3.12 & 0.30 & 1.05 & 0.39 & 0.40 \\
\hline $3-4$ & 1.66 & 1.59 & 0.48 & 3.73 & 0.30 & 1.05 & 0.35 & 0.34 \\
\hline $4-5$ & 1.41 & 1.37 & 0.40 & 3.19 & 0.29 & 1.03 & 0.49 & 0.50 \\
\hline $5-6$ & 2.04 & 1.96 & 0.58 & 4.58 & 0.29 & 1.04 & 0.38 & 0.39 \\
\hline $6-7$ & 1.24 & 1.27 & 0.33 & 2.85 & 0.26 & 0.98 & 0.49 & 0.53 \\
\hline $7-8$ & 1.38 & 1.45 & 0.40 & 3.23 & 0.28 & 0.96 & 0.35 & 0.39 \\
\hline $8-9$ & 1.27 & 1.15 & 0.37 & 2.79 & 0.32 & 1.10 & 0.38 & 0.36 \\
\hline $9-10$ & 1.08 & 1.08 & 0.31 & 2.47 & 0.29 & 1.01 & 0.40 & 0.44 \\
\hline $10-11$ & 1.46 & 1.48 & 0.41 & 3.36 & 0.28 & 0.98 & 0.40 & 0.43 \\
\hline $11-12$ & 1.24 & 1.25 & 0.37 & 2.86 & 0.29 & 0.99 & 0.34 & 0.35 \\
\hline $12-13$ & 0.97 & 0.91 & 0.29 & 2.17 & 0.32 & 1.07 & 0.39 & 0.37 \\
\hline $13-14$ & 1.05 & 0.89 & 0.32 & 2.26 & 0.36 & 1.18 & 0.43 & 0.40 \\
\hline $14-15$ & 1.11 & 1.11 & 0.37 & 2.59 & 0.34 & 1.00 & 0.49 & 0.51 \\
\hline $15-16$ & 1.38 & 1.32 & 0.53 & 3.23 & 0.40 & 1.05 & 0.50 & 0.47 \\
\hline $16-17$ & 1.53 & 1.38 & 0.59 & 3.50 & 0.43 & 1.11 & 0.46 & 0.41 \\
\hline average & 1.34 & 1.30 & 0.41 & 3.05 & 0.32 & 1.04 & 0.41 & 0.42 \\
\hline s.d. & 0.25 & 0.25 & 0.09 & 0.58 & 0.04 & 0.06 & 0.05 & 0.06 \\
\hline \multicolumn{9}{|c|}{ Central prodelta Flood deposit Core J13-II } \\
\hline $0-0.5$ & 0.81 & 0.77 & 0.23 & 1.81 & 0.30 & 1.05 & 0.49 & 0.49 \\
\hline $0.5-1$ & 1.08 & 0.97 & 0.30 & 2.35 & 0.31 & 1.12 & 0.48 & 0.47 \\
\hline $1-2$ & 1.09 & 0.99 & 0.32 & 2.39 & 0.32 & 1.10 & 0.44 & 0.40 \\
\hline $2-3$ & 0.92 & 0.82 & 0.29 & 2.03 & 0.35 & 1.13 & 0.47 & 0.44 \\
\hline $3-4$ & 0.87 & 0.78 & 0.28 & 1.94 & 0.36 & 1.12 & 0.39 & 0.35 \\
\hline $4-5$ & 0.74 & 0.75 & 0.26 & 1.75 & 0.35 & 0.99 & 0.46 & 0.45 \\
\hline $5-6$ & 0.85 & 0.69 & 0.43 & 1.98 & 0.62 & 1.23 & 0.45 & 0.48 \\
\hline average & 0.91 & 0.82 & 0.30 & 2.03 & 0.37 & 1.11 & 0.45 & 0.44 \\
\hline s.d. & 0.13 & 0.11 & 0.06 & 0.25 & 0.11 & 0.07 & 0.03 & 0.05 \\
\hline
\end{tabular}

salinities and relatively low material in suspension (Fig. 5) suggested that southern distributaries supplied a significant amount of fresh water while most of their particulate supply was trapped in the shallow prodelta because of flocculation and settling processes. Alternatively, a fraction of sediment load could have settled even before reaching the sea within the distributary channels (Fox et al., 2004). Indeed, based on published data for the Goro distributary, Syvistki et al. (2005b) estimated a net sediment accumulation along this southern channel, accounting for $16 \%$ of the total annual sediment entering the delta. The authors calculated sediment deposition rates for the Goro channel that range from 4.7 to $5.7 \mathrm{~cm} \mathrm{yr}^{-1}$, relatively higher than sedimentation rates measured in most of the prodelta (Frignani et al., 2005). As a result, the Goro channel floor is becoming super-elevated compared to the surrounding delta flood plain (Syvistki et al., 2005b).

As SSC in surface waters did not exhibit any statistical difference between dry periods (Boldrin et al., 2005) and moderate discharge, our results suggest that there must be a 


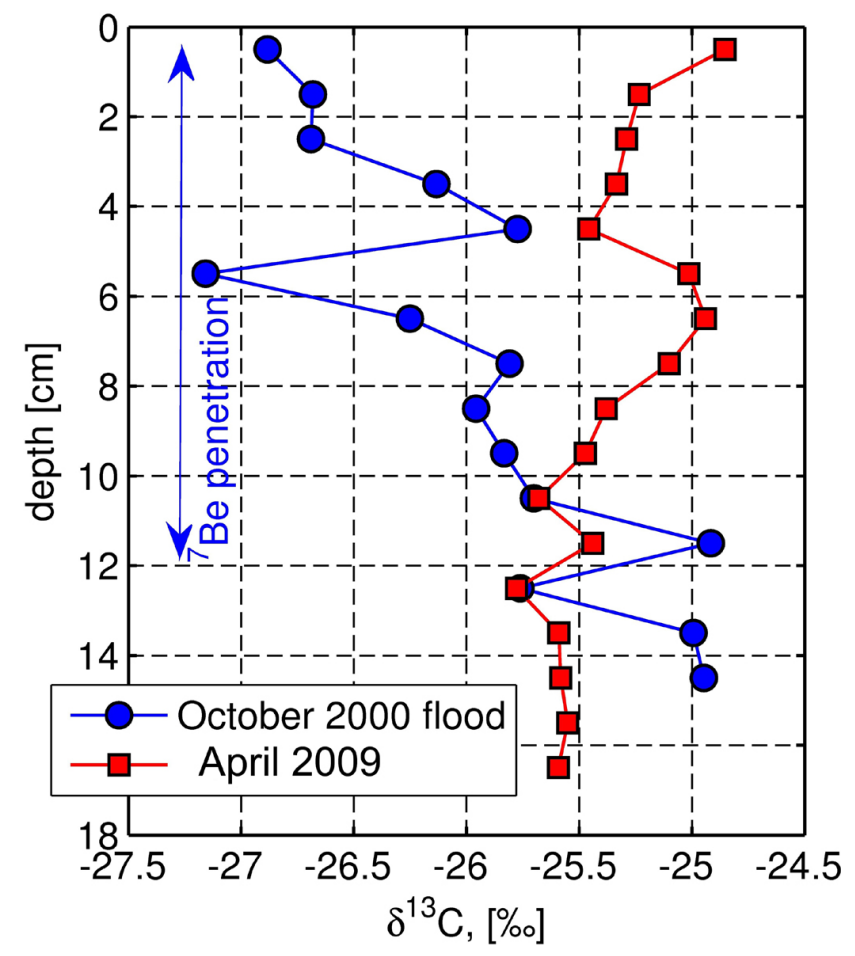

Fig. 7. Down-core profiles of $\delta^{13} \mathrm{C}$. Filled circles show the N14 core collected in December 2000 (Miserocchi et al., 2007). Solid line shows the ${ }^{7}$ Be penetration (Palinkas et al., 2005) in December 2000. Filled squares show the N14 core collected on 30 April 2009. In this latter sediment core ${ }^{7} \mathrm{Be}$ was not detected.

threshold level for the river discharge after which the plume can ultimately penetrate into the prodelta. Based on differences in SSC and transmittance values observed between moderate and peak discharge, this threshold level has to be between $\sim 5000$ and $\sim 8000 \mathrm{~m}^{3} \mathrm{~s}^{-1}$. However, the SSC values during the peak discharge were still lower than expected suggesting that even the second sampling carried out on 1 May did not fully represent the settling and emplacement mechanisms described by Milligan et al. (2007) with the exception of the region just off the Pila mouth, where the whole water column exhibited unambiguous evidences of particles settling from the upper plume (Fig. 5).

It is also important to highlight, that there are other unknown variables such as sediment availability that may affect the land-ocean exchange of particulate material in a multichannel setting. Specifically, the aforementioned threshold level might change depending on the time that elapses between two floods. During these low to moderate discharge periods, a fraction of river-borne sediment accumulate along channels and riverbed forming an ephemeral deposit. This material can be subsequently resuspended when the flow increases during flood events. In this aspect, the October 2000 flood was extremely different from the May 2009 flood, not only because of the flood magnitude and duration, but also because the October 2000 flood was a discrete event whereas the May 2009 flood occurred at the end of a series of flood events (Fig. 2) close to each other that might have cleaned up both channels and riverbed.

\subsection{Accumulation in the prodelta during ordinary floods}

Indirect evidence from sediment cores supports our hypothesis that most of the sediment supply to the prodelta occurs mainly when the river experiences particularly intense and extensive flood events. Figure 6 shows sediment cores collected in the Po prodelta after a long period of intense precipitations that resulted in a series of flood events between 4000 and $6000 \mathrm{~m}^{3} \mathrm{~s}^{-1}$ (8 events, Fig. 2b). However, in spite of the relatively high river flow, most of the cores collected did not show clear evidence of recent deposition. The northern prodelta just off the Pila mouth (E transect) exhibited relatively high ${ }^{7} \mathrm{Be}$ penetrations and evidence of laminated beddings in shallow water (i.e., E11 core). However, thicknesses were extremely small compared to the October 2000 flood that resulted in a thick deposit in the same stations (Table 6) (Wheatcroft et al., 2006). The rest of the cores collected in the prodelta showed bioturbated sediment fabric and extremely low ${ }^{7} \mathrm{Be}$ penetrations, such as in the central prodelta $(1-2 \mathrm{~cm})$, or even no detectable ${ }^{7} \mathrm{Be}$, such as in the southern prodelta at the N14 station. If considerable sediment deposition had occurred in the prodelta as a result of these eight ordinary flood events preceding the May 2009 flood, we should have observed significant penetrations of ${ }^{7} \mathrm{Be}$ and/or seen laminated beddings. For example, indications of event-strata preservation of the October 2000 flood were observed throughout the prodelta by means of radiographs and ${ }^{7} \mathrm{Be}$ inventory several months after the flood and in some stations up to two years since the flood emplacement (Palinkas et al., 2005; Wheatcroft et al., 2006). Therefore, the relatively modest deposition in the prodelta - despite the numerous events - suggests that the material delivered during ordinary floods ( $2-3 \mathrm{yr}$ return periods) is mainly trapped in shallower waters or within distributary channels (Fox et al., 2004), whereas during large flood events, such as the October 2000 flood, sediments can efficiently reach the midlle and distal prodelta. This does not necessarily imply that sedimentation does not occur during ordinary floods. A fraction of flood-derived material probably accumulates on the seabed, but the thicknesses of these deposits are probably not sufficient to compete with post-depositional processes such as bioturbation and wave-supported sediment transport.

The effect of ordinary vs. extra-ordinary floods on the terrigenous OC burial was particularly marked in the southern part of the prodelta. In this region, about two months after the peak of the October 2000 flood, a 12-cm thick eventstratum was observed at the station N14 based on radiographs and ${ }^{7} \mathrm{Be}$ penetration (Palinkas et al., 2005; Wheatcroft et al., 2006). In addition, the first $10 \mathrm{~cm}$ of this sediment 
core showed relatively depleted $\delta^{13} \mathrm{C}$ values, indicating deposition of fresh terrigenous OC at the top of the core (Miserocchi et al., 2007). The same target was re-occupied in May 2009 and, although the river experienced 8 floods from November 2008 through May 2009, the sediment core was highly bioturbated and lacked of ${ }^{7} \mathrm{Be}$ activity (Fig. 6; Table 5). Furthermore, the $\delta^{13} \mathrm{C}$ did not show any evidence of deposition of fresh terrigenous OC at the upper core (Fig. 7). Therefore, the paradox that a significant amount of fresh water entered the southern delta during flood events, without showing evidence of recent deposition in the sediment record, supports, once again, the hypothesis that most of the material delivered during ordinary floods by the southern distributaries is trapped in shallow regions and/or within the distributary channels, consistent with water column results. Consequently, sediment accumulation in this location is driven by other mechanisms including southerly current events forced by winds and wave-supported turbidity flows, as suggested by modeling and in-situ tripod measurements (Traykovski et al., 2007). Therefore, most of the accumulated material in the southern prodelta is likely reworked material whose bulk composition is significantly different from fresh terrigenous OC (Fig. 7).

\subsection{The May 2009 flood deposit}

Although Pila and Tolle belong to the same network of channels, their outlets exhibit contrasting geomorphologic features. The Tolle distributary was the dominant channel until the end of the Little Ice Age whereas Pila became dominant at the end of the 19th century (Correggiari et al., 2005) in response to the artificial E-W straightening of the main feeding river trunk. Today Tolle is dominated by wave and exhibits an estuary-like river mouth characterized by sandy barriers (wave-dominated delta) (Fig. 1) (Correggiari et al., 2005). Conversely, in the northern region, the prodelta experiences significant progradation resulting in a seaward migration of the Pila outlet (river-dominated delta) (Fig. 1) (Correggiari et al., 2005). Stations off Pila and Tolle mouths were reoccupied after the peak of the flood on 5 May. Core E16-II was collected in the northern prodelta whereas core J13-II was taken in the central region. These sites were re-occupied because they exhibited among the highest SSC values measured in the surface plume on 1 May during the peak of the flood. Comparing radiographs and ${ }^{7} \mathrm{Be}$ penetrations before and after the peak discharge, we estimated event-layers 17 and $6 \mathrm{~cm}$ thick in the northern and central prodelta, respectively. Deposition in the Pila region was expected based on settling and flocculation processes observed during the peak on 1 May (Fig. 5). Conversely, settling from the surface plume was not detected off the Tolle mouth on 1 May suggesting that conditions sufficient to cause accumulation in the central region were likely reached the following day since the peak of the flood lasted for two days until 2 May. Therefore, besides absolute peak discharge, the length of the flood
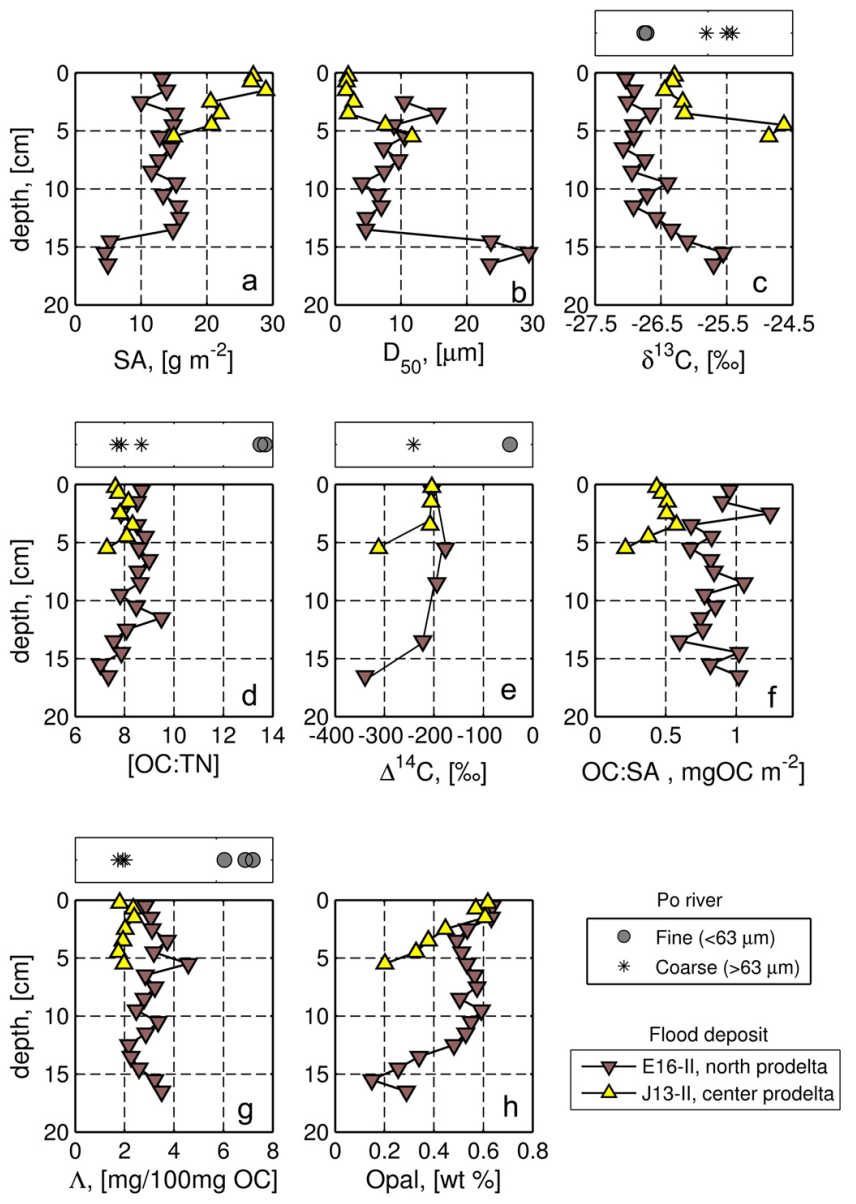

Fig. 8. Down-core variability in flood deposits collected in the northern (E16-II) and central (J13-II) prodelta vs. material collected in the Po river: (a) SA (Surface Area), (b) $D_{50}$, (median grain size) (c) $\delta^{13} \mathrm{C}$, (d) OC:TN, (e) $\Delta^{14} \mathrm{C}$, (f) OC:SA, (g) $\Lambda$, and (h) Opal.

is clearly another factor that enhances the plume thickness (Milligan et al., 2007) that in turn increases the residence time of particles within the turbid plume allowing for the deposition in the prodelta.

It is worth highlighting that in addition to having a different thickness these event-strata displayed significant differences in the sediment texture (Fig. 8a, b). Grain-size distribution in two intervals from each core was used to examine these differences (Fig. 9a). Bimodal grain-size distribution was observed in the flood deposit collected in the northern prodelta (E16-II). For the most part of this core, the most frequent size classes were at the silt-clay boundary $(\sim 4 \mu \mathrm{m})$ and in the silt fraction $(\sim 35 \mu \mathrm{m})$. Conversely, the flood deposit collected in the central prodelta (J13-II) exhibited a normal distribution centered at the silt-clay size boundary $(\sim 4 \mu \mathrm{m})$. The missing peak in the silt fraction for this latter core indicates that settling of silty material occurred prior to reaching the central prodelta. Indeed, the geomorphologic architecture of Tolle mouth, characterized by an estuary-like feature 

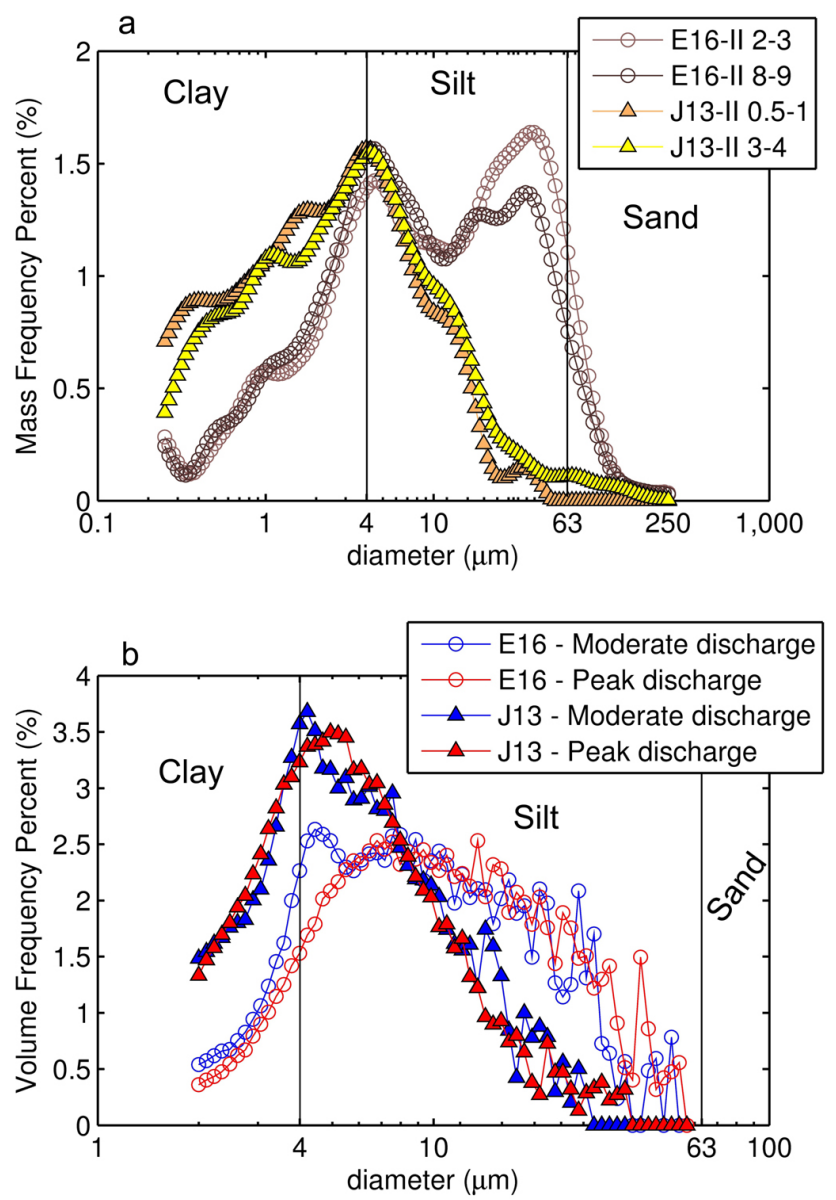

Fig. 9. (a) Grain-size distribution of E16-II and J13-II sediment core. Two intervals are shown for each core (Sedigrapher). (b) Grain-size distribution of surface water suspended sediments at E16 and J13 stations (Coulter counter).

(Fig. 1), suggests that the material enters the Adriatic Sea via this distributary as a buoyancy-driven plume rather than a momentum-driven flow (Syvitski et al., 2005a). As a result of the reduced transport capacity, the coarse material is selectively trapped prior to reaching the sea within the Tolle mouth.

Particle size distribution in surface water samples $(\sim 1 \mathrm{~m}$ below the sea surface) collected above E16 and J13 stations highlights similar spatial differences (Fig. 9b). In both moderate and peak discharges, the northern prodelta exhibited a coarser sediment texture in suspended sediments relative to the central region. In addition, as the particle size distribution remained fairly constant despite the increase of river discharge, these results might imply that sediment texture in the surface plume during a flood event is mainly driven by the delta architecture rather than the discharge extent.

\subsection{OC composition}

\subsubsection{River samples and flood deposits}

Fine and coarse suspended sediments collected on 23 April 2009 at Pontelagoscuro gauging station ( $\mathrm{H}$ event in Fig. 2b) displayed contrasting compositions in both bulk and biomarker parameters (Tables 1 and 2). Specifically, the coarse fraction exhibited higher OC:TN ratios, relatively depleted $\delta^{13} \mathrm{C}$, significantly higher lignin contents, and a younger ${ }^{14} \mathrm{C}$ age. Based on these differences, we can conclude that the OC in the coarse fraction $(>63 \mu \mathrm{m})$ was primarily composed of relatively young organic plant detritus, whereas the fine fraction $(<63 \mu \mathrm{m})$ was mainly affected by aged, humified OC bound to the mineral soil (Fig. 8).

Event-strata collected in the northern (E16-II) and central prodelta (J13-II), in addition to having a distinct grainsize, showed contrasting OC compositions concerning $\Lambda$ and $\delta^{13} \mathrm{C}(p<0.01)$ (Fig. 8c, g). This analogy suggests that coarse and fine particles display a different composition as well as coarse and fine fractions of river samples. However, the OC loading in both deposits are within the range of the mono-layer equivalent (Mayer, 1994), indicating that most of the OC is associated with the mineral matrix of inorganic particles (Fig. 8f). Therefore, rather than mixing of matrix-free vascular plant detritus with soil-derived OC, as seen for river samples, differences between flood deposits might be the result of diverse terrigenous OC coated on different particles (i.e., organo-clay complexes vs. organo-silt complexes). Besides OC loading, other parameters support this conclusion. For example, in both flood deposits OC:TN ratios are within the range of soil-derived OC (Hedges and Oades, 1997). In parallel, for both deposits radiocarbon measurements $\left({ }^{14} \mathrm{C}\right)$ indicated an aged $\mathrm{OC}$ source rather than a relatively fresh vascular plant detritus (Fig. 8d, c) as observed for the coarse fraction collected in the river. In addition, proxies for microbial degradation of terrigenous OC such as the acid to aldehyde ratios of the vanillyl phenols ([Vd:Vl]) and syringyl ([Sd:Sl]) do not indicate any differences between deposits, consistent with elemental and radiocarbon results (Table 7). It is also important to highlight that granulometric classes of the coarse and fine material for suspended river samples and flood deposits are not identical. Suspended river material was sieved with a $63 \mu \mathrm{m}$ mesh to separate the mud (clay + silt) from the sand fraction whereas most of the differences between flood deposits were due to a different proportions of silt $(4-63 \mu \mathrm{m})$ and clay $(<4 \mu \mathrm{m})$. Therefore, results from the size fractionation of river samples can not be directly applied to flood deposits. It is also interesting to observe that both flood deposits had a sandysilty basal stratum that, despite a significant contribution of sand, had a divergent composition relative to the coarse fraction collected in the river. These coarse basal strata had relatively old radiocarbon ages, low OC:TN ratios and displayed an enriched $\delta^{13} \mathrm{C}$ compositions. Therefore, the terrigenous 
OC mixing within a flood deposit is probably more complex than a simple mixture of coarse material, relatively rich in modern vascular plant detritus, with fine material, relatively rich in aged, humified soil-derived OC. In addition, dilution with lignin-free organic matter in the central prodelta (J13-II core), such as algal material, might explain the lower lignin contents as well as the enriched $\delta^{13} \mathrm{C}$ values. However, opal contents in the event-strata does not support the hypothesis of autochthonous OC burial being particularly significant in the Tolle region (Fig. 8h). If significant algal burial had occurred in the central prodelta, we should have measured higher relative opal contents in this area as diatoms constitute the predominant fraction of autochthonous production in the Po prodelta (Aubry et al., 2004).

Finally, the relative proportions of lignin phenols in suspended material and sediments provide details on vascular plant tissue origin. Specifically, concentrations of cinnamyl relative to vanillyl phenols ([C:V] ratio) is used to differentiate between woody and non-woody plants, whereas concentrations of syringyl relative to vanillyl phenols ([S:V] ratio) is used to distinguish angiosperm from gymnosperm tissues (Hedges and Mann, 1979; Hedges et al., 1986). Coarse and fine fractions in suspended material collected in the Po river displayed relatively similar $[\mathrm{C}: \mathrm{V}]$ and $[\mathrm{S}: \mathrm{V}]$ ratios, despite the contrasting biogeochemical compositions. In parallel flood deposits collected in northern and central prodelta exhibited similar $[\mathrm{C}: \mathrm{V}]$ and $[\mathrm{S}: \mathrm{V}]$ ratios (Table 7). This indicates that the relative proportion of lignin phenols is fairly homogeneous throughout the channels network as well as among different size fractions (i.e., coarse vs. fine).

\subsubsection{Surface plume}

In prodeltas, suspended particulate $\mathrm{OC}$ is a heterogeneous mixture of different compounds coming from different sources including vascular plant detritus, organic matter sorbed onto the surface of suspended particles, as well as estuarine and marine phytoplankton (Fry and Sherr, 1984; Hedges and Oades, 1997; Chanton and Lewis, 1999; Goñi et al., 2003, 2008). As the aforementioned OC sources exhibit contrasting compositions, biogeochemical parameters such as OC, TN, $\delta^{13} \mathrm{C}$ and $\Lambda$ constitute a useful toolbox to infer the OC provenance. Average compositions of different OC sources are shown in Fig. 10 as boxes according to the literature (Fry and Sherr, 1984; Hedges and Oades, 1997; Goñi et al., 2003, 2005). On top we have plotted river and prodelta samples to visually examine the influence of autochthonous and allochthonous OC sources on these samples.

Significant differences were observed between suspended material and sediment cores collected in the Po prodelta. Sediments were mainly affected by river-borne material, whereas autochthons production was the dominant OC source of suspended samples (Fig. 10). However, suspended material collected during the peak discharge just off Pila and Tolle mouths exhibited a significant influence of terrigenous
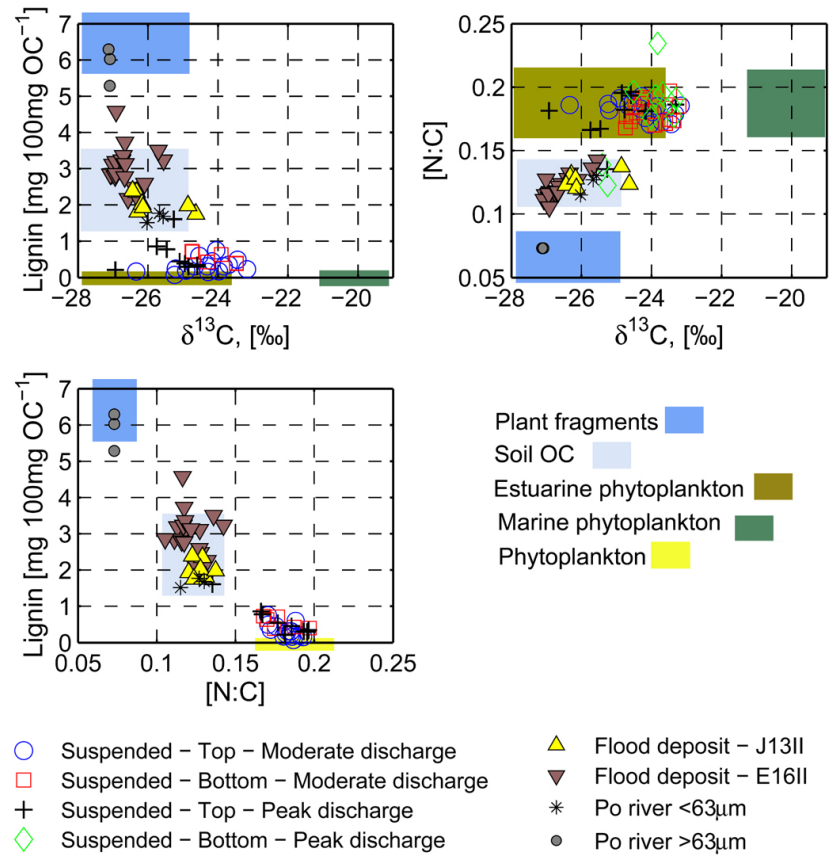

Fig. 10. Sources of OC in Po river samples, suspended materials and flood deposits collected in the Po prodelta. Boxes show the relative contribution of allochthonous and autochthonous OC according to the average values in literature (Fry and Sherr, 1984; Hedges et al., 1986; Goñi et al., 2003; Harmelin-Vivien et al., 2008).

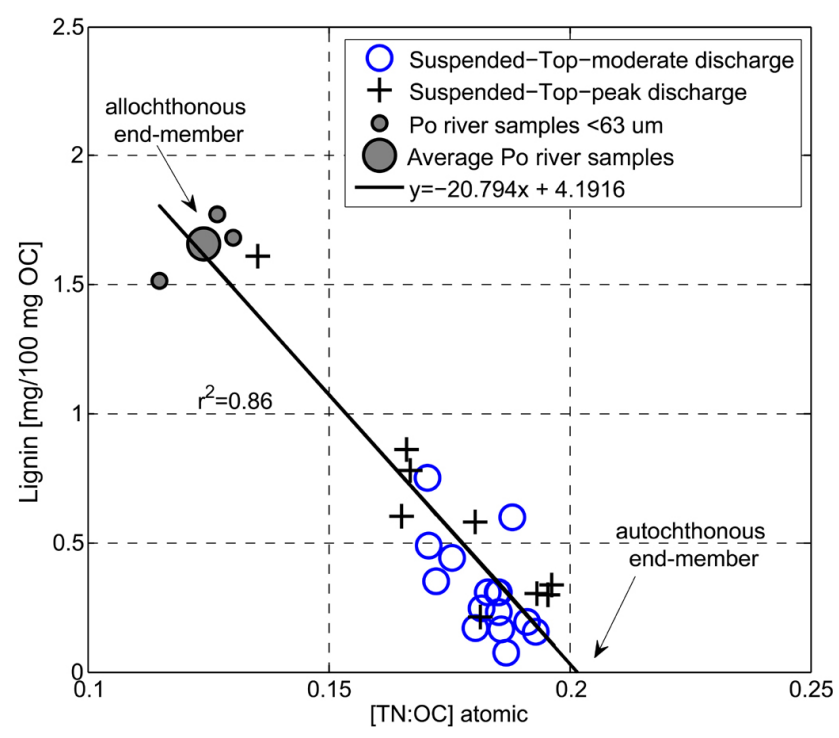

Fig. 11. Plot of TN:OC vs. lignin. Open circles and crosses are surface suspended sediments collected during moderate and peak flood, respectively. Filled circles are fine material $(<63 \mu \mathrm{m})$ collected in the Po river. Solid line is the regression line. 

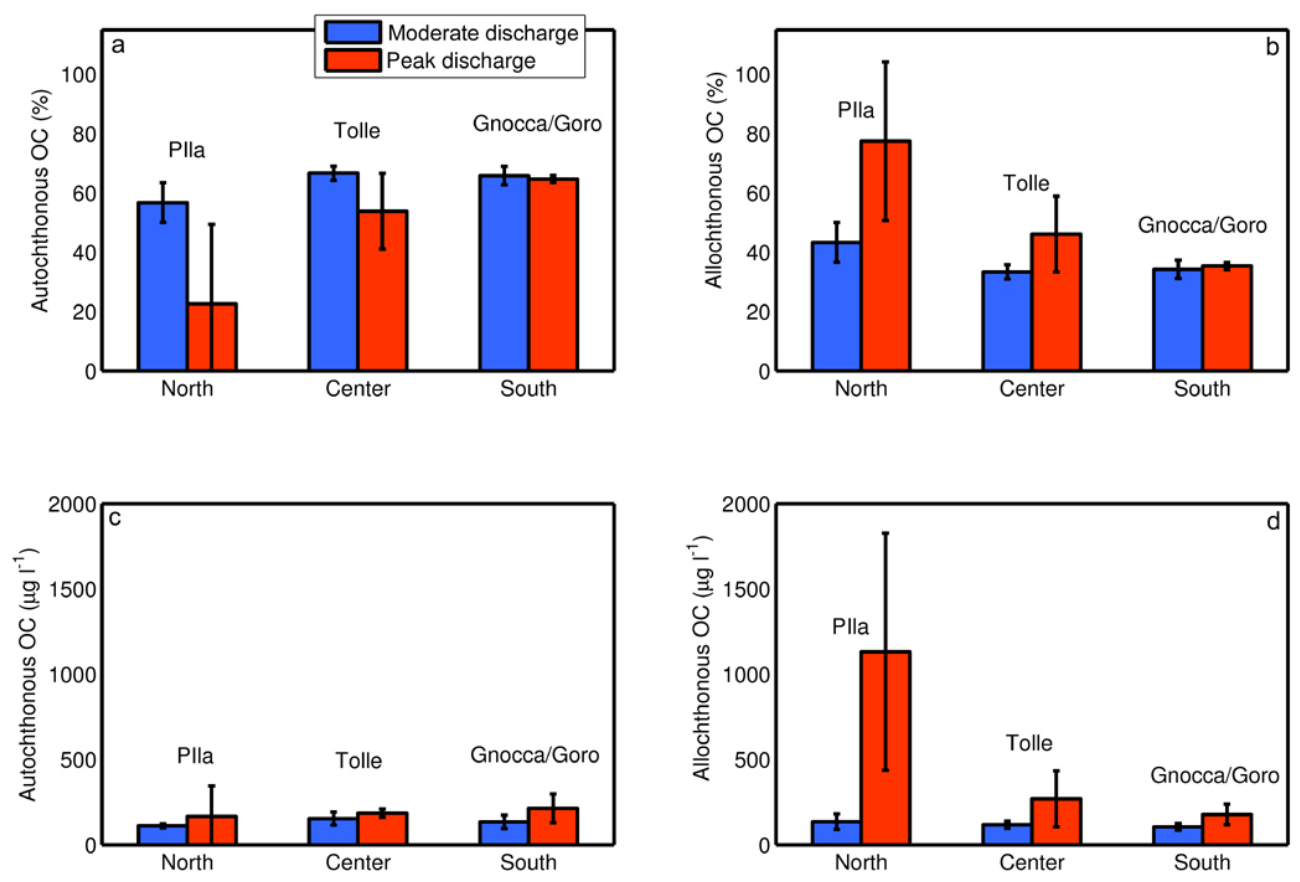

Fig. 12. Results from the end-member mixing model. Surface suspended samples were grouped in three sub-regions according to the latitude: north, center, south. Blue and red bars represent samples collected during moderate and peak discharge, respectively. (a) Fraction of autochthonous OC, (b) Fraction of allochthonous OC, (c) Concentration of autochthonous OC in the surface plume, and (d) Concentration of allochthonous OC in the surface plume.

OC. A two end-member mixing model was used to quantify the influence of land-derived material and autochthonous phytoplankton in the surface plume. Previous studies in the Po prodelta have assessed the relative contribution of estuarine and marine phytoplankton using elemental compositions (OC/TN ratio) and $\delta^{13} \mathrm{C}$ data (Boldrin et al., 2005; Giani et al., 2009). However, while the marine end-member can be assumed to be relatively stable in the model, the estuarine phytoplankton exhibits a broad range of $\delta^{13} \mathrm{C}$ values (Chanton and Lewis, 1999). This occurs because of the mixing of fresh water with seawater. This latter is in equilibrium with the atmospheric $p \mathrm{CO}_{2}(\sim-7 \% o)$ (Mook, 1986) whereas the fresh water is relatively depleted in ${ }^{13} \mathrm{C}$ due to terrigenous biomass degradation. Therefore, at any given mixture of sea water and fresh water, the ${ }^{13} \mathrm{C}$ signature of the dissolved $\mathrm{CO}_{2}$ changes affecting the isotopic signature of autochthonous phytoplankton (Chanton and Lewis, 1999). In parallel, this process influences the radiocarbon age of phytoplankton as the $\mathrm{CO}_{2}$ supplied by rivers is generally ${ }^{14} \mathrm{C}$ depleted compared to the atmosphere due to the degradation of aged terrigenous biomass. Similar mechanisms occur in upwelling region where aged water masses supply isotopically depleted $\mathrm{CO}_{2}$ to the surface ocean (Eglinton et al., 1997).

For this reason, we preferred to group together estuarine and marine algae and apply a simple two end-member mixing model between autochthonous and allochthonous OC using TN:OC and $\Lambda$ values (Fig. 11). The relative fraction of these sources have been assessed based on the position on the regression line $\left(r^{2}=0.87\right)$ that includes surface suspended material collected in the plume and fine river samples $(<63 \mu \mathrm{m})$ since the $D_{50}$ in all suspended sediments were significantly lower than $63 \mu \mathrm{m}$ (Table 3). Positions on the regression line were defined based on the minimum distance between samples and the regression line. An averaged value for the Po river fine fraction $(<63 \mu \mathrm{m})$ was used as endmember for the material supplied by the river. As phytoplankton is a lignin-free OC source, the intercept for $\Lambda=0$ was used to define the [TN:OC] value for the autochthonous end-member. The relative fractions of autochthonous and allochthonous $\mathrm{OC}$ were then converted in $\mu \mathrm{g} \mathrm{OC} \mathrm{L}^{-1}$.

Figure 12 shows the results from the model. Samples were grouped in three sub-regions (i.e. north, central, south) according to collection sites. Results are shown as mean and relative standard deviation for each sub-region. The relative fraction of autochthonous OC exhibited an overall increase with distance from the Pila mouth, especially during the peak of the flood (Fig. 12a). The concentration of autochthonous $\mathrm{OC}\left(\mu \mathrm{gL}^{-1}\right)$ was slightly higher during the peak discharge, though these differences were not statistically significant (Fig. 12b). However, these similar concentrations indicate that phytoplankton growth was not limited by the increase in water turbidity, especially in the southern prodelta where we observed the highest autochthonous OC concentrations during the peak discharge, consistent with 
fluorometer data (Fig. 5). During the peak of the flood, the relative fraction of allochthonous OC increased throughout the prodelta (Fig. 12c). Terrigenous material in the Pila region became the major OC whereas in the central and southern prodelta allochthonous and autochthonous fractions were fairly even despite the high discharge. Concentrations of land-derived $\mathrm{OC}\left(\mu \mathrm{g} \mathrm{L}^{-1}\right)$ were statistically higher during the peak of the flood relative to the early stage of the flood $(P<0.01)$ (Fig. 12d). However, with the exception of the Pila region, central and southern prodelta exhibited terrigenous concentrations 1-2 fold less concentrated than the river $\left(5173 \pm 392 \mu \mathrm{g} \mathrm{OCL}^{-1}\right.$, Table 1) indicating that, despite the peak of the flood, flocculation, dilution, and settling processes were still affecting the concentration of terrigenous OC within the plume.

\section{Summary}

This study investigated the event-driven supply and deposition of land-derived material in the Po prodelta characterized by a multi-channel architecture. The overall conclusions of this study are that (i) the land-ocean exchange of particulate $\mathrm{OM}$ is constrained by the delta architecture and (ii) the material supplied to the prodelta is not coherent throughout the network of channels . The following are specific findings:

1. Po river discharge exerts first-order control on the terrigenous OM concentration within the plume. Specifically, our results suggest the there must be a threshold level for the river discharge over which the turbid plume can efficiently penetrate into the prodelta. Based on differences in suspended sediment concentrations measured in the surface plume during moderate and peak discharge, this level has to be between $\sim 5000$ and $\sim 8000 \mathrm{~m}^{3} \mathrm{~s}^{-1}$. Below this value, most of the terrigenous $\mathrm{OM}$ is likely sequestered in shallow waters and/or within distributary channels. These trapping processes are particularly marked in the central and southern prodelta where the flow through distributarychannels is not sufficient to compensate settling and flocculation processes even during relatively high discharge.

2. Similarly, results from sediment cores indicate that significant deposition in the prodelta occurs only during particularly large flood events. During ordinary floods ( $\left.\sim 4000-6000 \mathrm{~m}^{3} \mathrm{~s}^{-1}\right)$ only a small fraction of material can reach the deep region of the prodelta. As a result, sediment accumulation is not sufficient to balance post-depositional processes (e.g., bioturbation and storm-induced waves) resulting in a weak preservation of event-strata.

3. In both moderate and peak discharges, the relative fraction of terrigenous OC decreased with distance from the main distributary of the Po river (Pila mouth). In spite of this north-to-south decrease, concentrations of allochthonous OC exhibited an overall increase throughout the prodelta because of the flood, especially in the northern prodelta. In the southern prodelta, a thick layer of fresh water characterized by relatively low SSC was observed during the peak of the flood. In this region, autochthonous OC was the main OC source even during the peak flood. This suggests that settling processes, coupled with significant input of fresh water, are key factors for phytoplankton blooms during flood events in the southern prodelta.

4. After the peak of the flood, a silty flood deposit was collected just off the Pila outlet in the northern prodelta, while finer event-event strata were collected in front of the Tolle mouth in the central prodelta. Differences in grain-size were likely due to the estuary-like architecture of the central prodelta that caused trapping of relatively coarse material prior to reaching the sea. In addition, these flood deposits exhibited contrasting biogeochemical compositions including OC loading, $\delta^{13} \mathrm{C}$, and concentrations of lignin phenols. This analogy suggested that hydrodynamic sorting affected also the supply and deposition of terrestrially-derived OM prior to reaching the prodelta. In spite of these sorting processes, lignin-based parameters indicated that the composition of vascular plant tissues supplied to the prodelta is fairly homogenous throughout the network of channels and between size-fractions.

Acknowledgements. The authors would like to acknowledge the FP7-Marie Curie Action who provided funding for this work under grant (SOMFlood project, Grant Agreement number: PIOF-GA2008-221167). We also thank M. Claret Cortes, A. Gallerani, A. Remia, Y. Alleau, and J. Snyder for their help in the field and in the lab. Special thanks go to the captain E. Gentile and to crew of the R/V Urania. This is contribution number 1708 of CNR-ISMAR, sede di Bologna.

Edited by: N. Ohkouchi

\section{References}

Aubry, F. B., Berton, A., Bastianini, M., Socal, G., and Acri, F.: Phytoplankton succession in a coastal area of the NW Adriatic, over a 10-year sampling period (1990-1999), Cont. Shelf Res., 24, 97-115, 2004.

Berner, R. A.: Models for Carbon and Sulfur Cycles and Atmospheric Oxygen - Application to Paleozoic Geologic History, Am. J. Sci., 287, 177-196, 1987.

Berner, R. A.: Biogeochemical Cycles of Carbon and Sulfur and Their Effect on Atmospheric Oxygen over Phanerozoic Time, Global Planet. Change, 75, 97-122, 1989.

Blair, N. E., Leithold, E. L., Ford, S. T., Peeler, K. A., Holmes, J. C., and Perkey, D. W.: The persistence of memory: The fate 
of ancient sedimentary organic carbon in a modern sedimentary system, Geochim. Cosmochim. Ac., 67, 63-73, 2003

Boldrin, A., Langone, L., Miserocchi, S., Turchetto, M., and Acri, F.: Po River plume on the Adriatic continental shelf: Dispersion and sedimentation of dissolved and suspended matter during different river discharge rates, Mar. Geol., 222, 135-158, 2005.

Burnelli, A. and Moramarco, T.: Saltalippi Valutazione dei profili di velocità in canali naturali per eventi di piena eccezionali. XXX Convegno di Idraulica e Costruzioni Idrauliche - IDRA, 2006.

Chanton, J. P. and Lewis, F. G.: Plankton and dissolved inorganic carbon isotopic composition in a river-dominated estuary: Apalachicola Bay, Florida, Estuaries, 22, 575-583, 1999.

Correggiari, A., Cattaneo, A., and Trincardi, F.: The modern Po Delta system: Lobe switching and asymmetric prodelta growth, Mar. Geol., 222, 49-74, 2005.

Demaster, D. J.: The Supply and Accumulation of Silica in the Marine-Environment, Geochim. Cosmochim. Ac., 45, 17151732, 1981.

Eglinton, T. I., BenitezNelson, B. C., Pearson, A., McNichol, A. P., Bauer, J. E., and Druffel, E. R. M.: Variability in radiocarbon ages of individual organic compounds from marine sediments, Science, 277, 796-799, 1997.

Fox, J. M., Hill, P. S., Milligan, T. G., and Boldrin, A.: Flocculation and sedimentation on the Po River Delta, Mar. Geol., 203, 95107, 2004

Frignani, M., Langone, L., Ravaioli, M., Sorgente, D., Alvisi, F., and Albertazzi, S.: Fine-sediment mass balance in the western Adriatic continental shelf over a century time scale, Mar. Geol., 222, 113-133, 2005.

Fry, B. and Sherr, E. B.: Delta-C-13 Measurements as Indicators of Carbon Flow in Marine and Fresh-Water Ecosystems, Contrib. Mar. Sci., 27, 13-47, 1984.

Giani, M., Berto, D., Rampazzo, F., Savelli, F., Alvisi, F., Giordano, P., Ravaioli, M., and Frascari, F.: Origin of sedimentary organic matter in the north-western Adriatic Sea, Estuar. Coast. Shelf S., 84, 573-583, 2009.

Gomez, B., Trustrum, N. A., Hicks, D. M., Rogers, K. M., Page, M. J., and Tate, K. R.: Production, storage, and output of particulate organic carbon: Waipaoa River basin, New Zealand, Water Resour. Res., 39(6), 1161, doi:10.1029/2002WR001619, 2003.

Goñi, M. A. and Montgomery, S.: Alkaline $\mathrm{CuO}$ oxidation with a microwave digestion system: Lignin analyses of geochemical samples, Anal. Chem., 72, 3116-3121, 2000.

Goñi, M. A., Ruttenberg, K. C., and Eglinton, T. I.: A reassessment of the sources and importance of land-derived organic matter in surface sediments from the Gulf of Mexico, Geochim. Cosmochim. Ac., 62, 3055-3075, 1998.

Goñi, M. A., Teixeira, M. J., and Perkey, D. W.: Sources and distribution of organic matter in a river-dominated estuary (Winyah Bay, SC, USA), Estuar. Coast. Shelf S., 57, 1023-1048, 2003.

Goñi, M. A., Yunker, M. B., Macdonald, R. W., and Eglinton, T. I.: The supply and preservation of ancient and modem components of organic carbon in the Canadian Beaufort Shelf of the Arctic Ocean, Mar. Chem., 93, 53-73, 2005.

Goni, M. A., Monacci, N., Gisewhite, R., Crockett, J., Nittrouer, C., Ogston, A., Alin, S. R., and Aalto, R.: Terrigenous organic matter in sediments from the Fly River delta-clinoform system (Papua New Guinea), J. Geophys. Res., 113, F01S10, doi:10.1029/2006JF000653, 2008 .
Gordon, E. S. and Goñi, M. A.: Sources and distribution of terrigenous organic matter delivered by the Atchafalaya River to sediments in the northern Gulf of Mexico, Geochim. Cosmochim. Ac., 67, 2359-2375, 2003.

Harmelin-Vivien, M., Loizeau, V., Mellon, C., Beker, B., Arlhac, D., Bodiguel, X., Ferraton, F., Hermand, R., Philippon, X., and Salen-Picard, C.: Comparison of $\mathrm{C}$ and $\mathrm{N}$ stable isotope ratios between surface particulate organic matter and microphytoplankton in the Gulf of Lions (NW Mediterranean), Cont. Shelf Res., 28, 1911-1919, 2008.

Hedges, J. I. and Mann, D. C.: Characterization of Plant-Tissues by Their Lignin Oxidation-Products, Geochim. Cosmochim. Ac., 43, 1803-1807, 1979.

Hedges, J. I. and Keil, R. G.: Sedimentary Organic-Matter Preservation - an Assessment and Speculative Synthesis, Mar. Chem. 49, 81-115, 1995.

Hedges, J. I. and Oades, J. M.: Comparative organic geochemistries of soils and marine sediments, Org. Geochem., 27, 319-361, 1997.

Hedges, J. I., Clark, W. A., Quay, P. D., Richey, J. E., Devol, A. H., and Santos, U. D.: Compositions and Fluxes of Particulate Organic Material in the Amazon River, Limnol. Oceanogr., 31, 717-738, 1986.

Kettner, A. J. and Syvitski, J. P. M.: Fluvial responses to environmental perturbations in the Northern Mediterranean since the Last Glacial Maximum, Quaternary Sci. Rev., 28, 2386-2397, 2009.

Leithold, E. L., Blair, N. E., and Perkey, D. W.: Geomorphologic controls on the age of particulate organic carbon from small mountainous and upland rivers, Global Biogeochem. Cy., 20, GB3022, doi:10.1029/2005GB002677, 2006.

Mayer, L. M.: Surface-Area Control of Organic-Carbon Accumulation in Continental-Shelf Sediments, Geochim. Cosmochim. Ac., 58, 1271-1284, 1994.

Milliman, J. D. and Syvitski, J. P. M.: Geomorphic Tectonic Control of Sediment Discharge to the Ocean - the Importance of Small Mountainous Rivers, J. Geol., 100, 525-544, 1992.

Milligan, T. G., Hill, P. S., and Law, B. A.: Flocculation and the loss of sediment from the Po River plume, Cont. Shelf Res., 27, 309-321, 2007.

Miserocchi, S., Langone, L., and Tesi, T.: Content and isotopic composition of organic carbon within a flood layer in the Po River prodelta (Adriatic Sea), Cont. Shelf Res., 27, 338-358, 2007.

Mortlock, R. A. and Froelich, P. N.: A Simple Method for the Rapid-Determination of Biogenic Opal in Pelagic MarineSediments, Deep-Sea Res., 36, 1415-1426, 1989.

Mook, W. G.: ${ }^{13} \mathrm{C}$ in atmospheric $\mathrm{CO}_{2}$, Neth. J. Sea Res., 20, $211-$ 223, 1986.

Onstad, G. D., Canfield, D. E., Quay, P. D. and Hedges, J. I.: Sources of particulate organic matter in rivers from the continental USA: Lignin phenol and stable carbon isotope compositions, Geochim. Cosmochim. Ac., 64, 3539-3546, 2000.

Opsahl, S. and Benner, R.: Early Diagenesis of Vascular PlantTissues - Lignin and Cutin Decomposition and Biogeochemical Implications, Geochim. Cosmochim. Ac., 59, 4889-4904, 1995.

Palinkas, C. M., Nittrouer, C. A., Wheatcroft, R. A., and Langone, L.: The use of Be-7 to identify event and seasonal sedimentation near the Po River delta, Adriatic Sea, Mar. Geol., 222, 95-112, 
2005.

Syvitski, J. P. M. and Kettner, A. J.: On the flux of water and sediment into the Northern Adriatic Sea, Cont. Shelf Res., 27, 296308, 2007.

Syvitski, J. P. M., Kettner, A. J., Correggiari, A., and Nelson, B. W.: Distributary channels and their impact on sediment dispersal, Mar. Geol., 222, 75-94, 2005a.

Syvitski, J. P. M., Vorosmarty, C. J., Kettner, A. J., and Green, P.: Impact of humans on the flux of terrestrial sediment to the global coastal ocean, Science, 308, 376-380, 2005b.

Syvitski, J. P. M., Kettner, A. J., Overeem, I., Hutton, E. W. H., Hannon, M. T., Brakenridge, G. R., Day, J., Vorosmarty, C., Saito, Y., Giosan, L., and Nicholls, R. J.: Sinking deltas due to human activities, Nat. Geosci., 2, 681-686, 2009.

Tesi, T., Langone, L., Goñi, M. A., Miserocchi, S. and Bertasi, F.: Changes in the composition of organic matter from prodeltaic sediments after a large flood event (Po River, Italy), Geochim. Cosmochim. Ac., 72, 2100-2114, 2008.
Tramontano, J. M. and Church, T. M.: A technique for the removal of estuarine seston from nuclepore filters, Limnol. Oceanogr., 29, 1339-1341, 1984.

Traykovski, P., Wiberg, P. L., and Geyer, W. R.: Observations and modeling of wave-supported sediment gravity flows on the Po prodelta and comparison to prior observations from the Eel shelf, Cont. Shelf Res., 27, 375-399, 2007.

Wheatcroft, R. A., Stevens, A. W., Hunt, L. M., and Milligan, T. G.: The large-scale distribution and internal geometry of the fall 2000 Po River flood deposit: Evidence from digital Xradiography, Cont. Shelf Res., 26, 499-516, 2006.

Wheatcroft, R. A., Goñi, M. A., Hatten, J. A., Pasternack, G. B., and Warrick, J. A.: The role of effective discharge in the ocean delivery of particulate organic carbon by small, mountainous river systems, Limnol. Oceanogr., 55, 161-171, 2010. 